\title{
STRUCTURE AND PROPERTIES OF ZnSnP 2 WITH THE APPLICATION IN PHOTOVOLTAIC DEVICES BY USING CdS AND ZnTe BUFFER LAYERS
}

\author{
DNeeraja, (D) Ajay S. Verma ${ }^{\mathrm{b}, *}$ \\ ${ }^{a}$ Department of Physics, Banasthali Vidyapith, Rajasthan 304022 (India) \\ ${ }^{b}$ Department of Natural and Applied Sciences, School of Technology, Glocal University \\ Saharanpur, Uttar Pradesh, 247232 (India) \\ *Corresponding Author: ajay_phy@rediffmail.com, Mobile: +919412884655 \\ Received November 1, 2020; revised December 15, 2020; accepted February 13, 2021
}

\begin{abstract}
Here in, we present the extensive analysis of the parameters associated with structural, electronic, optical and mechanical properties of zinc-based chalcopyrite material by using full potential linearized augmented plane wave method (FP-LAPW) within framework on the density functional theory. Ab initio calculations have been performed by the linearized augmented plane wave (LAPW) method as implemented in the WIEN2K code within the density functional theory to obtain the structural, electronic and optical properties of $\mathrm{ZnSnP} 2$ in the body centered tetragonal (BCT) phase. The six elastic constants $\left(\mathrm{C}_{11}, \mathrm{C}_{12}, \mathrm{C}_{13}, \mathrm{C}_{33}, \mathrm{C}_{44}\right.$ and $\left.\mathrm{C}_{66}\right)$ and mechanical parameters have been presented and compared with the available experimental data. The thermodynamic calculations within the quasi-harmonic approximation is used to give an accurate description of the pressure-temperature dependence of the thermal-expansion coefficient, bulk modulus, specific heat, Debye temperature, entropy Grüneisen parameters. Based on the semi-empirical relation, we have determined the hardness of the material; which attributed to different covalent bonding strengths. Further, $\mathrm{ZnSnP}_{2}$ solar cell devices have been modeled; device physics and performance parameters have analyzed for $\mathrm{ZnTe}$ and $\mathrm{CdS}$ buffer layers. Simulation results for $\mathrm{ZnSnP} \mathrm{P}_{2}$ thin layer solar cell show the maximum efficiency (22.9\%) with $\mathrm{ZnTe}$ as the buffer layer. Most of the investigated parameters are reported for the first time. The result of the present study further validates the prospects of using this chalcopyrite that would be inherently persistent and consistent with flexible substratum, those are the main features of commercialization chalcopyrite solar cells. Thus, promoting the evolution of this material, for achieving high performance based optoelectronic devices will pave a new path in solar cell industry.
\end{abstract}

KEYWORDS: Ab-initio calculations; electronic properties; elastic constants; thermodynamic properties

$\mathrm{ZnSnP}_{2}$ is a member of $\mathrm{A}^{\mathrm{II}} \mathrm{B}^{\mathrm{IV}} \mathrm{C}^{\mathrm{V}}$ group ternary compound semiconductors, which has with chalcopyrite structure as a new solar absorber. The growth of $\mathrm{ZnSnP} 2$ thin films has been prepared by co-evaporation and in ultra-high vacuum by molecular beam epitaxy (MBE). Recently [1], $\mathrm{ZnSnP}_{2}$ based thin-film solar cell is fabricated and also prepared energy band gap by phosphidation method under the variation of $\mathrm{Zn} / \mathrm{Sn}$ atomic ratio. Defects introduce localized levels in the energy gap of $\mathrm{ZnSnP}_{2}$ and other compound semiconductors through which they control solar cell device performance, efficiency and reliability. In $\mathrm{ZnSnP}_{2}$ thin film, zinc vacancies or zinc-on-tin sites are considered as acceptor. This is responsible for $\mathrm{p}$-type conductivity. $\mathrm{ZnSnP}_{2}$ is focused as a solar absorbing material consisting of safe and earth-abundant elements. Investigated the structures of interfaces related to the absorbing material $\mathrm{ZnSnP}_{2}$ to clarify the origin of high resistance and improve the photovoltaic performance in $\mathrm{ZnSnP}_{2}$ solar cells. The absorption coefficient of $\mathrm{ZnSnP}_{2}$ was reported to be approximately $10^{5} \mathrm{~cm}^{-1}$ in visible light range; $\mathrm{ZnSnP}_{2}$ has a promising property for a solar absorbing material. $\mathrm{ZnSnP}_{2}$ crystals for solar cells were prepared by mechanical-polishing [2,3].

Martinez et al [4], the $\mathrm{A}^{\mathrm{II}} \mathrm{B}^{\mathrm{IV}} \mathrm{C}^{\mathrm{V}}$ materials have similarly compelling electronic properties to their $\mathrm{A}^{\mathrm{II}} \mathrm{B}^{\mathrm{V}}$ counter parts. Materials can typically be doped both n-type and p-type using extrinsic impurities, and mobilities can be extremely high, with multiple reports. The phosphide and arsenide in $\mathrm{A}^{\mathrm{II}} \mathrm{B}^{\mathrm{IV}} \mathrm{CV}_{2}$ compounds have been synthesized in bulk form by three primary techniques; while optical properties have been studied using a combination of theory and experiment. Experimental work has been used to examine photoluminescence and absorption edge, while calculations can provide insight into physical mechanisms underlying these measurements [4]. $\mathrm{ZnSnP}_{2}$ has been proposed as a promising candidate for a solar absorbing material consisting of earth-abundant and safe elements. Solar absorbing materials composed of earth-abundant and safe elements have been investigated and $\mathrm{Cu}_{2} \mathrm{ZnSnS}_{4}-_{\mathrm{x}} \mathrm{Se}_{\mathrm{x}}, \mathrm{Cu}_{2} \mathrm{SnS}_{3}, \mathrm{Cu}_{2} \mathrm{O}, \mathrm{SnS}, \mathrm{Fe}_{2} \mathrm{~S}$, and $\mathrm{Zn}_{3} \mathrm{P}_{2}$ solar cells have been developed with a conversion efficiency of $12.6 \%$ [5]. The chalcopyrite compound $\mathrm{ZnSnP}_{2}$ is a promising candidate as a light absorber in solar cells since it has a direct band gap of $1.6 \mathrm{eV}$ [6]. Ternary $\mathrm{A}^{\mathrm{II}} \mathrm{B}^{\mathrm{IV}} \mathrm{C}_{2}$ chalcopyrite semiconductors $(\mathrm{Zn}, \mathrm{Cd})(\mathrm{Si}, \mathrm{Ge}, \mathrm{Sn})(\mathrm{P}, \mathrm{As})_{2}$ have band gap energies ranging from $2.1 \mathrm{eV}\left(\mathrm{ZnSiP}_{2}\right)$ to $0.67 \mathrm{eV}\left(\mathrm{ZnSnAs}_{2}\right)$ [6]. These materials have structural as well as electronic anomaly with higher energy gaps and lower melting points relative to their binary analogues, because of which they are considered to be important in crystal growth studies and device applications. Apart from it, the other important technological applications of these materials are in light emitting diodes, infrared detectors, infrared oscillations, etc [4-8]. $\mathrm{ZnSnP}_{2}$ semiconductors open up the possibility of fabricating a graded multijunction solar cell using the ordered chalcopyrite as the top layer, with progressively more disordered layers underneath, free from lattice matching problems [7-10]. A considerable amount of experimental and theoretical work related to the prediction of crystal structures, lattice constants, phase diagrams and related properties of these compounds has been done during the last few years [9-13]. In spite of all these works, it has been seen that the theoretical results obtained for elastic constants which experimentally need single crystals of these compounds differ considerably with the available experimental data [4-8]. 
In the present article, we have been investigated the structural, electronic, optical, elastic and thermal properties of $\mathrm{ZnSnP}_{2}$ in chalcopyrite phase. We have presented the theoretical study of expansion coefficient $(\alpha)$, heat capacities $\left(\mathrm{C}_{\mathrm{v}}\right.$ and $\left.\mathrm{C}_{\mathrm{p}}\right)$, bulk modulus ( $\mathrm{B}$ and $\left.\mathrm{B}^{\prime}\right)$, Debye temperature $\left(\theta_{\mathrm{D}}\right)$, hardness $(\mathrm{H})$ and Gruneisen parameter $(\gamma)$ of $\mathrm{ZnSnP}_{2}$; which are nevertheless scarce in literature. Calculated ground-state structural properties of the aforementioned crystals have been compared with available experimental and theoretical data. The outline of the paper is as follows. In section II we have given a brief review of the computational scheme used. The calculations of the fundamental physical properties have been described with the application point of view in solar cell device in section III; while the summary and conclusions are drawn in section VI.

\section{COMPUTATIONAL METHODS}

The calculations were done using FP-LAPW computational scheme $[14,15]$ as implemented in the WIEN2K code [16]. The FP-LAPW method expands the Kohn-Sham orbitals as atomic like orbitals inside the muffin-tin (MT) atomic spheres and plane waves in the interstitial region. The Kohn-Sham equations were solved using the recently developed Wu-Cohen generalized gradient approximation (WC-GGA) $[17,18]$ for the exchange-correlation (XC) potential. It has been shown that this new functional is more accurate for solids than any existing GGA and meta-GGA forms. For a variety of materials, it improves the equilibrium lattice constants and bulk moduli significantly over localdensity approximation [19] and Perdew-Burke-Ernzerhof (PBE) [20] and therefore is a better choice. For this reason, we adopted the new $\mathrm{WC}$ approximation for the $\mathrm{XC}$ potential in studying the present systems. Further for electronic structure calculations modified Becke-Johnson potential (mBJ) [21] as coupled with WC-GGA is used.

The valence wave functions inside the atomic spheres were expanded up to $l=10$ partial waves. In the interstitial region, a plane wave expansion with $R_{\mathrm{MT}} K_{\max }$ equal to seven was used for all the investigated systems, where $\mathrm{R}_{\mathrm{MT}}$ is the minimum radius of the muffin-tin spheres and $\mathrm{K}_{\max }$ gives the magnitude of the largest $\mathrm{K}$ vector in the plane wave expansion. The potential and the charge density were Fourier expanded up to $\mathrm{G}_{\max }=10$. We carried out convergence tests for the charge-density Fourier expansion using higher $G_{\max }$ values. The $\mathrm{R}_{\mathrm{MT}}$ (muffin-tin radii) are taken to be 2.2, 2.15 and 1.7 (in atomic unit) for $\mathrm{Zn}, \mathrm{Sn}$ and $\mathrm{P}$ respectively. The modified tetrahedron method [22] was applied to integrate inside the Brillouin zone (BZ) with a dense mesh of 5000 uniformly distributed k-points (equivalent to 405 in irreducible BZ) where the total energy converges to less than $10^{-6}$ Ry.

The computer simulation tool AMPS-1D (Analysis of Microelectronic and Photonic Structures) was employed by specifying semiconductor parameters as input in each layers of the cell.

\section{RESULTS AND DISSCUSSION Structural Properties}

The ternary chalcopyrite semiconductor crystallizes in the chalcopyrite structure with sapce group $I-\overline{42} d\left(D_{2 d}^{12}\right)$. The $\mathrm{Zn}$ atom is located at $(0,0,0) ;(0,1 / 2,1 / 4)$, Sn at $(1 / 2,1 / 2,0) ;(1 / 2,0,1 / 4)$ and $\mathrm{P}$ at $(\mathrm{u}, 1 / 4,1 / 8) ;(-\mathrm{u}, 3 / 4,1 / 8) ;(3 / 4, \mathrm{u}, 7 / 8)$; $(1 / 4,-u, 7 / 8)$. Two unequal bond lengths $d_{Z n-P}$ and $d_{S n-P}$ result in two structural deformations, first is characterized by $u$ parameter defined as $\mathrm{u}=0.25+\left(\mathrm{d}_{\mathrm{Zn}-\mathrm{P} 2}-\mathrm{d}_{\mathrm{Sn}-\mathrm{P} 2}\right) / \mathrm{a}^{2}$ where $\mathrm{a}$ is the lattice parameter in $\mathrm{x}$ and $\mathrm{y}$ direction, and the second parameter $\eta=c / a$, where $\mathrm{c}$ is lattice parameter in $\mathrm{z}$ direction which is generally different from $2 \mathrm{a}$.

To determine the best energy as a function of volume, we minimized the total energy of the system with respect to the other geometrical parameters. The minimization is done in two steps, first parameter $u$ is minimized by the calculation of the internal forces acting on the atoms within the unit cell until the forces become negligible, for this MINI task is used which is included in the WIEN2K code. Second, the total energy of crystal is calculated for a grid of volume of the unit cell (V) and c/a values, where each point in the grid involves the minimization with respect to u. Five values of c/a are used for each volume and a polynomial is then fitted to the calculated energies to calculate the best c/a ratio. The result is an optimal curve $(\mathrm{c} / \mathrm{a}, \mathrm{u})$ as a function of volume. Further a final optimal curve of total energy is obtained by minimizing the energy verses $[\mathrm{V}, \mathrm{c} / \mathrm{a}(\mathrm{V}), \mathrm{u}(\mathrm{V})]$ by FP-LAPW calculations and Murnaghan equation of state [23]. Table 1 present the lattice parameters ( $\mathrm{a}, \mathrm{c}$ and $\mathrm{u}$ ) and obtained along with the bulk modulus $(\mathrm{B})$ and its pressure derivative ( $\left.\mathrm{B}^{\prime}\right)$. The calculated total energy per unit as a function of volume is shown in Figure 1 (a).

\section{Electronic and optical properties}

The present calculations using the WC-mBJ method yields a direct band gap of $1.9 \mathrm{eV}$. As clear from the Figure 1 (b), that the obtained electronic band gap matches well with the experimental data predicted by Shaposhnikov et al [24]. Sahin et al [3] reported an estimate of the theoretical band gap as $1.06 \mathrm{eV}$. The comparison of the theoretical band gaps with available experimental data shows that $\mathrm{mBJ}$ correlation potential allows the prediction of band gap values much closer to the experimental values. The $\mathrm{mBJ}$ potential gives results in good agreement with experimental values that are similar to those produced by more sophisticated methods but at much lower computational costs [21].

To describe the general features of bonding in more detail the partial and total density for states (PDOS and DOS) at $0 \mathrm{GPa}$ pressure are calculated using the $\mathrm{mBJ}$ potential together with WC-GGA for the correlation (Figure 2). The DOS of different compounds considered share the similar features. For a clear understanding we divided the valence band region (VB) into three zones: low, intermediate and higher energy bands. For a better analysis, we have decomposed the total density of states into $\mathrm{s}, \mathrm{p}$ and $\mathrm{d}$ orbital contribution. Clearly, the low set of VBs ranging from $-11 \mathrm{eV}$ to $-10 \mathrm{eV}$ arise 
mainly from hybridized P s states, Sn p states and Sn s states. The intermediate energy sub bands situated at about $-9 \mathrm{eV}$ and $-5 \mathrm{eV}$ consists mainly of $\mathrm{Zn}$ d states. The upper valence band mainly consists of P p-states Sn $\mathrm{p}$ and $\mathrm{Zn} p$ states. The conduction bands near Fermi level are composed of strongly hybridized Sn s s-states and P p states with a few contributions of $\mathrm{Sn}$ p-states and P s states.

Table 1. Structural equilibrium parameters, a, c, u, B and B' calculated in WC-GGA and thermal properties at $300 \mathrm{~K}$; isothermal bulk modulus (B in GPa), Hardness (H in GPa), Gruneisen parameter $(\gamma)$, Debye temperature $\left(\theta_{\mathrm{D}}\right.$ in $\left.\mathrm{K}\right)$ and thermal expansion coefficient $\left(\alpha\right.$ in $10^{-5} / \mathrm{K}$ ) of $\mathrm{ZnSnP}_{2}$.

\begin{tabular}{|c|c|c|c|c|c|}
\hline $\begin{array}{c}\text { Structural } \\
\text { Analysis }\end{array}$ & $\mathrm{a}(\AA)$ & $\mathrm{c}(\AA)$ & $\mathrm{u}$ & $\mathrm{B}(\mathrm{GPa})$ & $\mathrm{B}^{\prime}$ \\
\hline & $5.69,5.65^{\mathrm{a},{ }^{*}}$ & $11.30,11.30^{\mathrm{a},{ }^{*}}$ & $0.253,0.25^{\mathrm{b},{ }^{*}}$ & $72,73^{\mathrm{b},{ }^{*}}$ & 4.59 \\
\hline Thermal Analysis & $\mathrm{B}(\mathrm{GPa})$ & $\mathrm{H}(\mathrm{GPa})$ & $\gamma$ & $\theta_{\mathrm{D}}(\mathrm{K})$ & $\alpha\left(10^{-5} / \mathrm{K}\right)$ \\
\hline & 67 & 4.82 & 1.863 & $354,352^{\mathrm{j}}$ & 4.512 \\
\hline
\end{tabular}

${ }^{\mathrm{a}}$ Reference [6]; ${ }^{\mathrm{b}}$ Reference [3]; ${ }^{\mathrm{j}}$ Reference [51]; ${ }^{*}$ Experimental

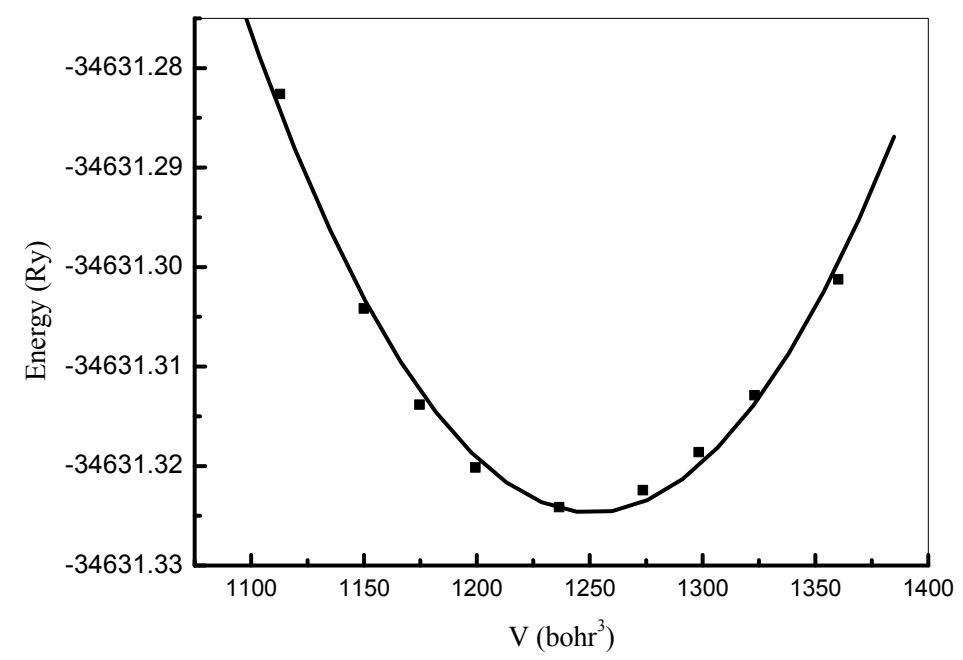

(a)

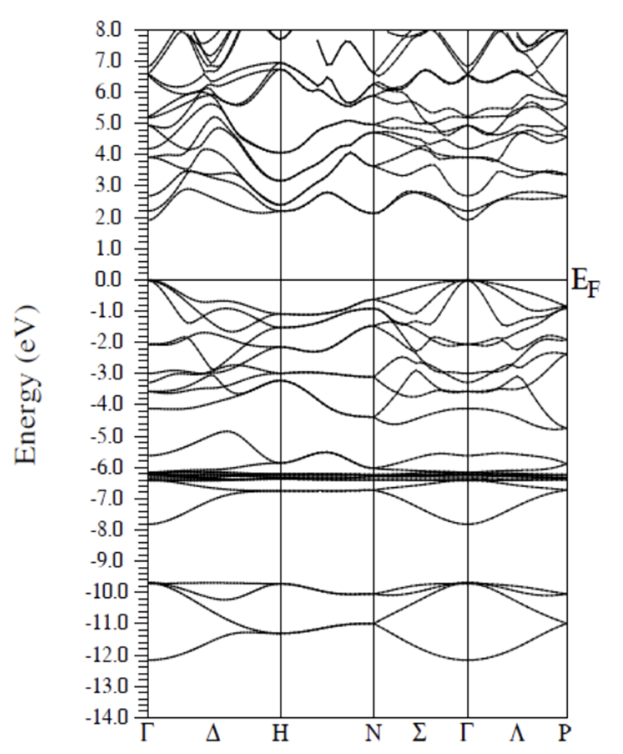

(b)

Figure 1. (a) Calculated total energies as a function of volume and (b) Band structures of $\mathrm{ZnSnP}_{2}$
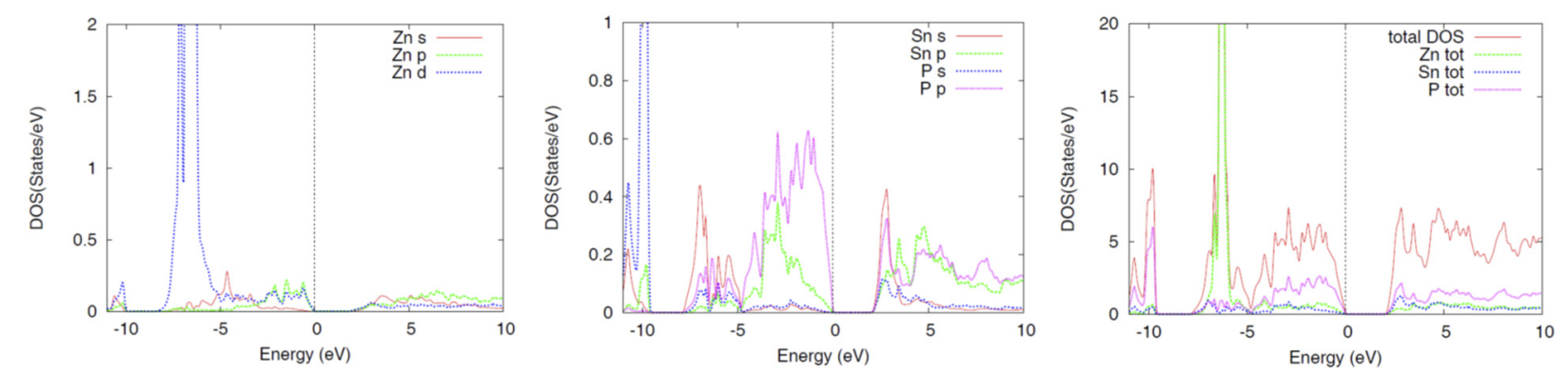

Figure 2. The calculated partial and total density of states (DOS) for $\mathrm{ZnSnP}_{2}$.

The linear response to an external electromagnetic field with a small wave vector is measured through the complex dielectric function,

$$
\varepsilon(\omega)=\varepsilon_{1}(\omega)+i \varepsilon_{2}(\omega)
$$

which is related to the interaction of photons with electrons [25]. The imaginary part $\varepsilon_{2}(\omega)$ of the dielectric function could be obtained from the momentum matrix elements between the occupied and unoccupied wave functions and is given by [26]

$$
\varepsilon_{2}(\omega)=\frac{2 \pi^{2} e^{2}}{\Omega \varepsilon_{0}} \sum_{i \in c . f \in v} \sum_{k}\left|\left\langle\Psi_{k}^{c}|\hat{\mu} . r| \Psi_{k}^{v}\right\rangle\right|^{2} \delta\left[E_{k}^{c}-E_{k}^{v}-\hbar \omega\right] .
$$

The real part $\varepsilon_{1}(\omega)$ can be evaluated from $\varepsilon_{2}(\omega)$ using the Kramer-Kronig relations and is given by [27] 


$$
\varepsilon_{1}(\omega)=1+\left(\frac{2}{\pi}\right) \int_{0}^{\infty} \frac{\omega^{\prime 2} \varepsilon_{2}\left(\omega^{\prime}\right)}{\omega^{\prime 2}-\omega^{2}} d \omega^{\prime}
$$

All of the other optical properties, including the absorption coefficient $\alpha(\omega)$, the refractive index $n(\omega)$, the extinction coefficient $\mathrm{k}(\omega)$, and the energy-loss spectrum $\mathrm{L}(\omega)$, can be directly calculated from $\varepsilon_{1}(\omega)$ and $\varepsilon_{2}(\omega)[26,28,29]$.

Figure 3 (a) and (b) displays the real and imaginary parts respectively of the electronic dielectric function $\varepsilon(\omega)$ spectrum for the photon energy ranging up to $40 \mathrm{eV}$, respectively.

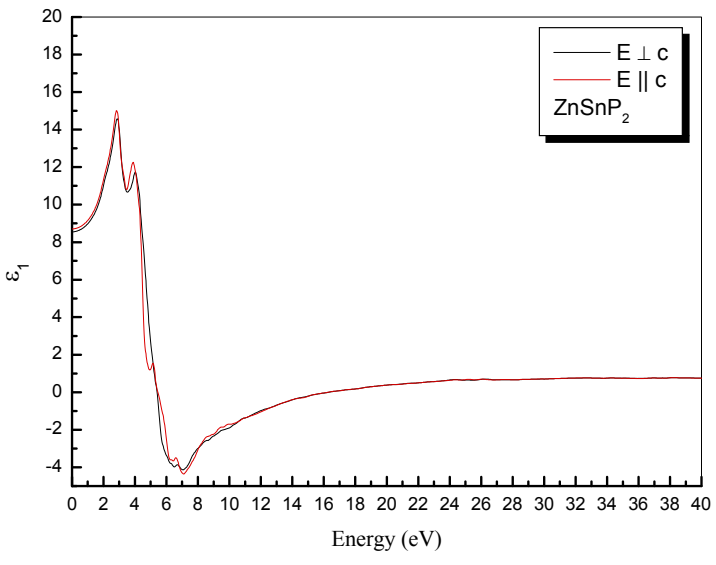

(a)

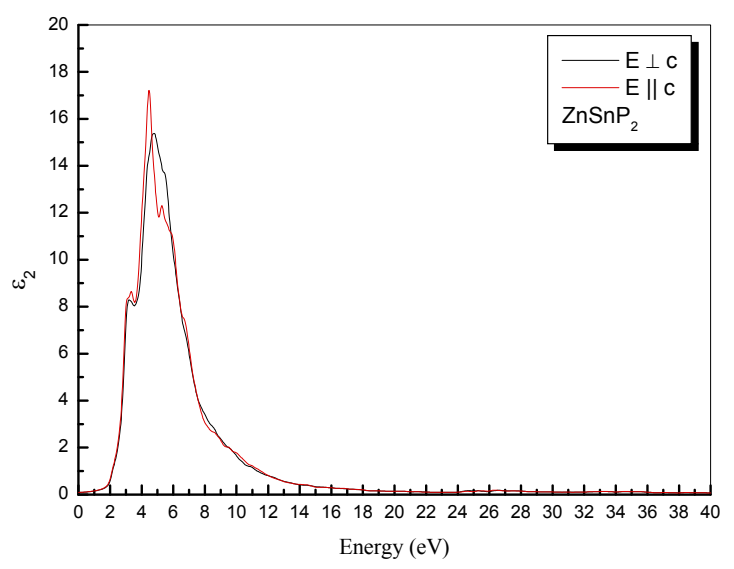

(b)

Figure 3. The calculated real $\varepsilon_{1}(\omega)$ and imaginary $\varepsilon_{2}(\omega)$ parts of complex dielectric constant for $\mathrm{ZnSnP}_{2}$.

The main peaks of $\varepsilon_{1}(\omega)$ which is mainly generated by electronic transition from the top of the valence band to the bottom of conduction band, occurs at $2.84 \mathrm{eV}(14.90)$ and $\varepsilon_{1}(\omega)$ spectra further decreases up to $7.10 \mathrm{eV}$. Optical spectra exhibit anisotropy in two directions (along basal-plane and z-axis) with a very small difference $(0.1543 \mathrm{eV})$ in the static limit. The imaginary part of the dielectric constant $\varepsilon_{2}(\omega)$ is the fundamental factor of the optical properties of a material. Figure 3 (b) displays the imaginary (absorptive) part of the dielectric function $\varepsilon_{2}(\omega)$ up to $40 \mathrm{eV}$. Our analysis shows that the critical points of the $\varepsilon_{2}(\omega)$ occurs at $1.80 \mathrm{eV}$. These points correspond to the $\Gamma_{\mathrm{c}}-\Gamma_{v}$ splitting which gives the threshold for the direct optical transitions between the absolute valence band maximum and the first conduction band minimum and is known as fundamental adsorption edge. The obtained fundamental edges are closely related to the obtained energy band gap values $1.9 \mathrm{eV}$.

Figure 4 (a) presents the refractive index $\mathrm{n}(\omega)$ along with the extinction coefficient $\mathrm{k}(\omega)$. The refractive index spectrum shows an anisotropic behavior $(\Delta \mathrm{n}(0 \mathrm{eV})=0.0263)$, hence only the averages are listed in (2.93737) Table 2. The peak value of refractive indices for $\mathrm{ZnSnP}_{2}$ is 3.88 at $2.94 \mathrm{eV}$.

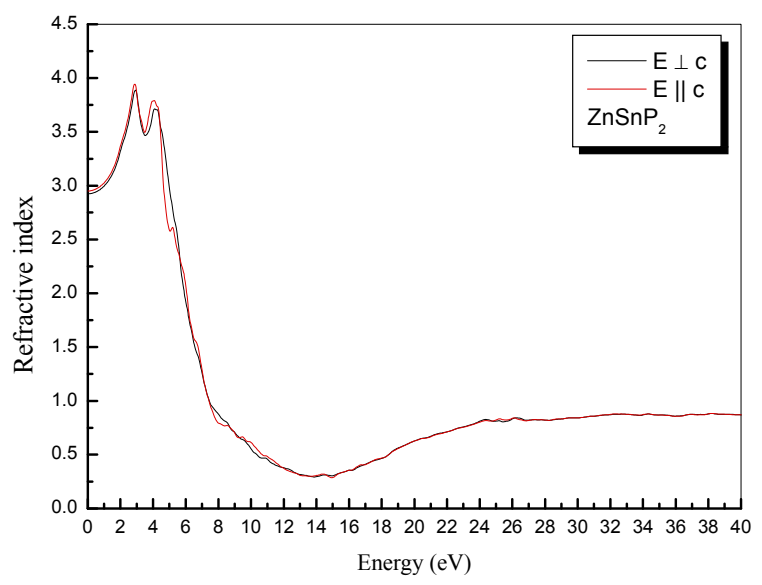

(a)

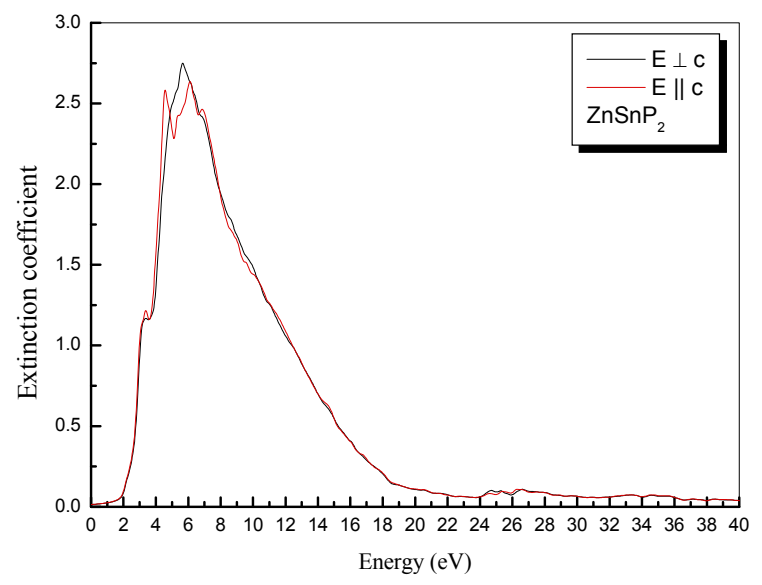

(b)

Figure 4. The calculated (a) refractive index and (b) extinction coefficient for $\mathrm{ZnSnP}_{2}$.

Figure 4 (b) show extinction coefficient $\mathrm{k}(\omega)$ is related to the decay or damping of the oscillation amplitude of the incident electric field, the extinction coefficient $\mathrm{k}(\omega)$ decreases with increasing the incident photon energy. The peak values obtained for the extinction coefficient occur at the points where the dispersive part of dielectric constant $\left(\varepsilon_{1}(\omega)\right.$ ) has a zero value (Figure 3 ) for all the compounds. The calculated optical reflectivity R ( $\omega$ ) is displayed in Figure 5 (a). 
These materials have small reflectivity in the low energy range. The maximum reflectivity occurs in region 4.54-13.92 eV [30].

Table 2. The calculated minimum band gaps $\mathrm{E}_{\mathrm{g}}(\mathrm{eV})$, refractive index (n) and dielectric constant for $\mathrm{ZnSnP}_{2}$ compared with other experimental and theoretical data.

\begin{tabular}{|c|c|c|c|}
\hline Crystals & $\mathrm{E}_{\mathrm{g}}(\mathrm{eV})$ this work & $\mathrm{n}$ this work & $\varepsilon_{\infty}$ this work \\
\hline $\mathrm{ZnSnP}_{2}$ & $1.9,1.5-1.7^{\mathrm{d}, *}, 1.06^{\mathrm{c}}, 1.66^{\mathrm{e}}$ & $2.93,2.90^{\mathrm{f}, *}$ & $8.62,9.7^{\mathrm{g}}$ \\
\hline
\end{tabular}

${ }^{\mathrm{d}}$ Reference [24]; ${ }^{\mathrm{c}}$ Reference [3]; ${ }^{\mathrm{e}}$ Reference [52]; ${ }^{\mathrm{f}}$ Reference [53]; ${ }^{\mathrm{g}}$ Reference [54]; ${ }^{\mathrm{E}}$ Experimental

The absorption coefficient is a parameter, which indicates the fraction of light lost by the electromagnetic wave when it passes through a unit thickness of the material. These have been plotted in Figure 5 (b). It is clear that polarization has a minor influence on the spectrum. From the absorption spectrum, we can easily find the absorption edges located at $1.89 \mathrm{eV}$. It is clear from the above discussion that both chalcopyrites are excellent mid-IR transparent crystal materials as they transparent to low energy photons showing zero value of the absorption coefficient in that region. When the photon energy is more than the absorption edge value, then adsorption coefficient increases. The absorption coefficients further decrease rapidly in the high energy region, which is the typical characteristic of semiconductors. Optical conductivity parameters are closely related to the photo-electric conversion efficiency and mainly used to measure the change caused by the illumination. Figure 5 (c) shows the optical conductivities of $\mathrm{ZnSnP}_{2}$. It's clear that the maximum photoconductivity of the materials lies in the $\mathrm{u}-\mathrm{v}$ region of electromagnetic spectrum.

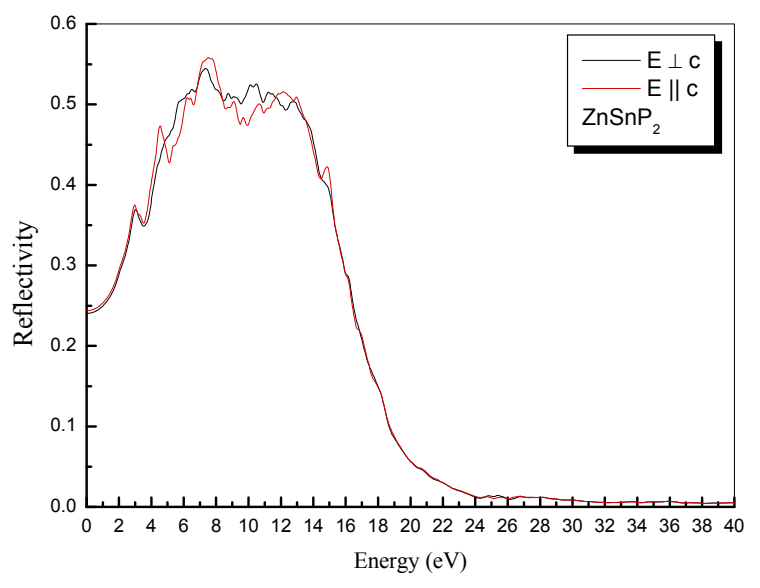

(a)

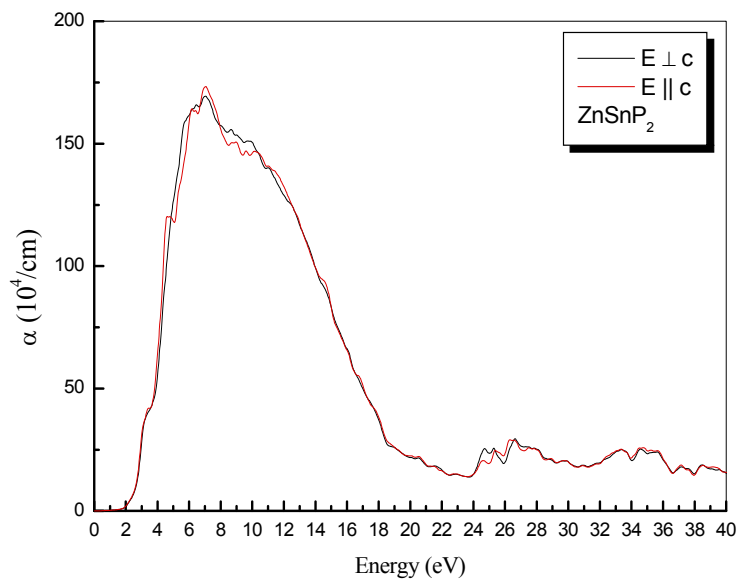

(b)

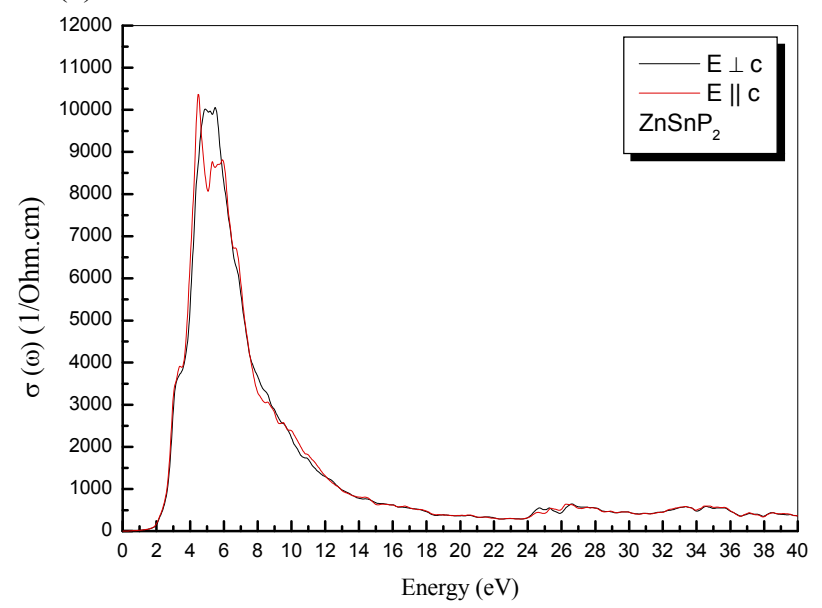

(c)

Figure 5. The calculated (a) reflectivity (R ( $\omega)$ ), (b) absorption coefficient $(\alpha(\omega))$ and (c) photoconductivity $(\sigma(\omega))$ for $\mathrm{ZnSnP} 2$.

\section{Elastic Properties}

The elastic properties of a solid are among the most fundamental properties that can be predicted from the firstprinciples ground-state total-energy calculations. The determination of the elastic constants requires knowledge of the curvature of the energy curve as a function of strain for selected deformations of the unit cell. The deformations [31] are shown in Table 3 and chosen such that the strained systems have the maximum possible symmetry. The system has been optimized for each deformed cell geometry. The WIEN2K package [16] facilitates this task by providing a force-driven optimization of the internal cell geometry. The elastic stiffness tensor of chalcopyrite compounds has six independent 
components because of the symmetry properties of the $D_{2 d}^{12}$ space group, namely $\mathrm{C}_{11}, \mathrm{C}_{12}, \mathrm{C}_{13}, \mathrm{C}_{33}, \mathrm{C}_{44}$ and $\mathrm{C}_{66}$ in Young notation. The calculated elastic constant for the tetragonal phase of $\mathrm{ZnSnP}_{2}$ are listed in Table 4.

Table 3. The lattice parameters of the deformed tetragonal unit cell, the expression relating the $\delta$ and $\varepsilon$ variables, the finite Lagrangian strain tensor (Voigt notation) and the value of the second derivative, $(1 / 2 \mathrm{~V})\left(\mathrm{d}^{2} \mathrm{E} / \mathrm{d} \varepsilon^{2}\right)$, in terms of the elastic constants $(\varepsilon$ being deformation coordinate and $\mathrm{E}$ the energy).

\begin{tabular}{|c|c|c|c|}
\hline Strained cell & $\varepsilon$ & Strain $(\eta)$ & $\mathrm{dE}^{2} / \mathrm{d} \varepsilon^{2}$ \\
\hline$\left(a+\delta, a+\delta, \frac{c+c \delta}{a}, 90,90,90\right)$ & $\frac{(a+\delta)^{2}}{a^{2}}-1$ & $\left(\frac{\varepsilon}{2}, \frac{\varepsilon}{2}, \frac{c \varepsilon}{2 a}, 0,0,0\right)$ & $\frac{1}{4}\left(C_{11}+C_{12}\right)+\frac{1}{8} C_{33}+\frac{1}{2} C_{13}$ \\
$(a+\delta, a+\delta, c, 90,90,90)$ & $\frac{(a+\delta)^{2}}{a^{2}}-1$ & $\left(\frac{\varepsilon}{2}, \frac{\varepsilon}{2}, 0,0,0,0\right)$ & $\frac{1}{4}\left(C_{11}+C_{12}\right)$ \\
$\left(a, a, \frac{c+c \delta}{a}, 90,90,90\right)$ & $\frac{(c+\delta)^{2}}{c^{2}}-1$ & $\left(0,0, \frac{\varepsilon}{2}, 0,0,0\right)$ & $\frac{1}{8} C_{33}$ \\
$(a, a+\delta, c, 90,90,90)$ & $\frac{(a+\delta)^{2}}{a^{2}}-1$ & $\left(0, \frac{\varepsilon}{2}, 0,0,0,0\right)$ & $\frac{1}{8} C_{11}$ \\
$(a, a, c, 90,90+\delta, 90)$ & $\sin \delta$ & $(0,0,0,0, \varepsilon, 0)$ & $C_{44}$ \\
$(a, a, c, 90,90,90+\delta)$ & $\sin \delta$ & $(0,0,0,0,0, \varepsilon)$ & $C_{66}$ \\
\hline
\end{tabular}

Table 4. Elastic constants $\mathrm{C}_{\mathrm{ij}}$ (in $\mathrm{GPa}$ ) of the $\mathrm{ZnSnP}_{2}$ compared with available data.

\begin{tabular}{|c|c|c|c|c|c|}
\hline $\mathrm{C}_{11}$ & $\mathrm{C}_{12}$ & $\mathrm{C}_{13}$ & $\mathrm{C}_{33}$ & $\mathrm{C}_{44}$ & $\mathrm{C}_{66}$ \\
\hline $105,110^{\mathrm{c}}$ & $53,53^{\mathrm{c}}$ & $53,51^{\mathrm{c}}$ & $103,106^{\mathrm{c}}$ & $50,47^{\mathrm{c}}$ & $50,49^{\mathrm{c}}$ \\
\hline $\mathrm{B}(\mathrm{GPa})$ & $\mathrm{G}(\mathrm{GPa})$ & $\mathrm{Y}(\mathrm{GPa})$ & $v$ & $\kappa_{\mathrm{a}}\left(\mathrm{GPa}^{-1}\right)$ & $\kappa_{\mathrm{c}}\left(\mathrm{GPa}^{-1}\right)$ \\
\hline 70 & 39 & 98 & 0.27 & 0.0047 & 0.0048 \\
\hline
\end{tabular}

${ }^{\mathrm{c}}$ Reference [3];

In general, the proposed results are in good agreement with the available data, in particular if we consider, shear constants $\left(\mathrm{C}_{44}\right.$ and $\left.\mathrm{C}_{66}\right)$ appear to be no worse than the rest of the elastic constants, even though the inner strain component is particularly difficult in those constants. The comparison with other theoretical calculations also shows an important dispersion of values. The calculated elastic constants fulfill the mechanical stability criteria for the tetragonal systems:

$$
\mathrm{C}_{11}>\left|\mathrm{C}_{12}\right|,\left(\mathrm{C}_{11}+\mathrm{C}_{12}\right) \mathrm{C}_{33}>2 \mathrm{C}_{13}^{2}, \mathrm{C}_{44}>0 \text {, and } \mathrm{C}_{66}>0
$$

In order to check the internal consistency of calculated elastic constants we can compare the bulk modulus reported on Table $1 \& 4$ with an equivalent combination of the $\mathrm{C}_{\mathrm{ij}}{ }^{\prime} \mathrm{s}$.

Bulk modulus should be found from above by the Voigt approximation (uniform strain assumption) [32, 33]:

$$
B_{V}=\frac{1}{9}\left(2 C_{11}+C_{33}+2 C_{12}+4 C_{13}\right)
$$

Reuss found lower bounds for all lattices [34]

$$
B_{R}=\frac{\left(C_{11}+C_{12}\right) C_{33}-2 C_{13}^{2}}{C_{11}+C_{12}+2 C_{33}-4 C_{13}}
$$

Voigt and Reuss approximations provide, in fact, an estimation of the elastic behaviour of an isotopic material, for instance a polycrystalline sample. Such a medium would have a single shear constant, G, upper bounded by

$$
G_{V}=\frac{1}{30}\left(M+3 C_{11}-3 C_{12}+12 C_{44}+6 C_{66}\right)
$$

and lower bounded by

$$
G_{R}=15\left\{\frac{18 B_{V}}{C^{2}}+\frac{6}{\left(C_{11}-C_{12}\right)}+\frac{6}{C_{44}}+\frac{3}{C_{66}}\right\}^{-1}
$$

where $C^{2}=\left(C_{11}+C_{12}\right) C_{33}-2 C_{13}^{2}$

In the Voigt-Reuss-Hill approximation [35], the $\mathrm{B}$ and $\mathrm{G}$ of the polycrystalline material are approximated as the arithmetic mean of the Voigt and Reuss limits:

$$
B=\frac{B_{V}+B_{R}}{2}
$$




$$
G=\frac{G_{V}+G_{R}}{2}
$$

Finally the Poisson ratio and the Young modulus are obtained as

$$
\begin{aligned}
& v=\frac{3 B-2 G}{2(3 B+G)} \\
& Y=\frac{9 B G}{3 B+G}
\end{aligned}
$$

Using the single crystal $C_{\mathrm{ij}}$ data, one can evaluate the linear compressibilities along the principles axis of the lattice. For the tetragonal structure, the linear compressibilities $\kappa_{a}$ and $\kappa_{c}$ along the a- and c-axis respectively are given in term of elastic constants by the following relations:

$$
\begin{aligned}
& \kappa_{a}=-\frac{1}{a} \frac{\partial a}{\partial p}=\frac{C_{33}-C_{13}}{C_{33}\left(C_{11}+C_{12}\right)-2 C_{13}^{2}} \\
& \kappa_{c}=-\frac{1}{c} \frac{\partial c}{\partial p}=\frac{C_{11}+C_{12}-2 C_{13}}{C_{33}\left(C_{11}+C_{12}\right)-2 C_{13}^{2}}
\end{aligned}
$$

Pugh [36] proposed that the resistance to plastic deformation is related to the product $\mathrm{Gb}$, where ' $\mathrm{b}$ ' is the Burgers vector, and that the fracture strength is proportional to the product $\mathrm{Ba}$, where ' $\mathrm{a}$ ' corresponds to the lattice parameter. As $\mathrm{b}$ and $\mathrm{a}$ are constants for specific materials, the $\mathrm{Ba} / \mathrm{Gb}$ can be simplified into $\mathrm{B} / \mathrm{G}$. This formula was recently exploited in the study of brittle vs ductile transition in intermetallic compounds from first-principles calculations [37, 38]. A high B/G ratio is associated with ductility, whereas a low value corresponds to the brittle nature. The critical value which separates ductile and brittle material is around 1.75, i.e., if $\mathrm{B} / \mathrm{G}>1.75$, the material behaves in a ductile manner otherwise the material behaves in a brittle manner. We have found that $\mathrm{B} / \mathrm{G}$ ratios is 1.82 for $\mathrm{ZnSnP}_{2}$, classifying the materials is ductile.

\section{Thermal Properties}

To investigate the thermodynamic properties of Zn-chalcopyrite, we have used Gibbs program. The obtained set of total energy versus primitive cell volume determined in previous section has been used to derive the macroscopic properties as a function of temperature and pressure from the standard thermodynamic relations. Gibbs program is based on the quasi-harmonic Debye model [39], in which the non-equilibrium Gibbs function $\mathrm{G}^{*}(\mathrm{~V} ; \mathrm{P}, \mathrm{T})$ can be written in the form of:

$$
G^{*}(V ; P, T)=E(V)+P V+A_{v i b}\left[\theta_{D} ; T\right]
$$

where $\mathrm{E}(\mathrm{V})$ is the total energy per unit cell, $\mathrm{PV}$ corresponds to the constant hydrostatic pressure condition, $\theta_{\mathrm{D}}$ is the Debye temperature, and $\mathrm{A}_{\mathrm{vib}}$ is the vibrational term, which can be written using the Debye model of the phonon density of states as $[40,41]$ :

$$
A_{v i b}\left[\theta_{D} ; T\right]=n k T\left[\frac{9 \theta}{8 T}+3 \ln \left(1-e^{-\theta / T}\right)-D\left(\frac{\theta}{T}\right)\right]
$$

where $\mathrm{n}$ is the number of atoms per formula unit, $\mathrm{D}(\theta / \mathrm{T})$ represents the Debye integral, and for an isotropic solid, $\theta$ is expressed as [40]:

$$
\theta_{D}=\frac{\hbar}{k}\left[6 \pi^{2} V^{1 / 2} n\right]^{1 / 3} f(\sigma) \sqrt{\frac{B_{S}}{M}}
$$

$\mathrm{M}$ being the molecular mass per unit cell and $\mathrm{B}_{\mathrm{S}}$ the adiabatic bulk modulus, approximated by the static compressibility [39]:

$$
B_{S} \cong B(V)=V \frac{d^{2} E(V)}{d V^{2}}
$$

$f(\sigma)$ is given by Refs. [39, 42, 43]; where $\sigma$ is the Poisson ratio.

Therefore, the non-equilibrium Gibbs function $\mathrm{G}^{*}(\mathrm{~V} ; \mathrm{P}, \mathrm{T})$ as a function of $(\mathrm{V} ; \mathrm{P}, \mathrm{T})$ can be minimized with respect to volume $\mathrm{V}$,

$$
\left(\frac{\partial G^{*}(V ; P, T)}{\partial V}\right)_{P, T}=0
$$

By solving Eq. (18), one can obtain the thermal equation of state (EOS) $\mathrm{V}(\mathrm{P}, \mathrm{T})$. The heat capacity $\mathrm{C}_{\mathrm{V}}$ and the thermal expansion coefficient $\alpha$ are given by [35], 


$$
\begin{gathered}
C_{V}=3 n k\left[4 D\left(\frac{\theta}{T}\right)-\frac{3 \theta / T}{e^{\theta / T}-1}\right] \\
S=n k\left[4 D\left(\frac{\theta}{T}\right)-3 \ln \left(1-e^{-\theta / T}\right)\right] \\
\alpha=\frac{\gamma C_{V}}{B_{T} V}
\end{gathered}
$$

where $\gamma$ is the Grüneisen parameter, which is defined as:

$$
\gamma=-\frac{d \ln \theta(V)}{d \ln V}
$$

Through the quasi-harmonic Debye model, one could calculate the thermodynamic quantities of any temperatures and pressures of compounds from the calculated $\mathrm{E}-\mathrm{V}$ data at $\mathrm{T}=0$ and $\mathrm{P}=0$.

We can also provide a prediction of the hardness ( $\mathrm{H}$ in $\mathrm{GPa}$ ) by using the semi-empirical equations developed by Verma and co-authors [44],

$$
\mathrm{H}=\mathrm{K} \mathrm{B}^{\mathrm{K}+1}
$$

$\mathrm{B}=$ Bulk modulus; $\mathrm{K}=0.59$ for $\mathrm{A}^{\mathrm{II}} \mathrm{B}^{\mathrm{IV}} \mathrm{C}_{2} \mathrm{~V}$

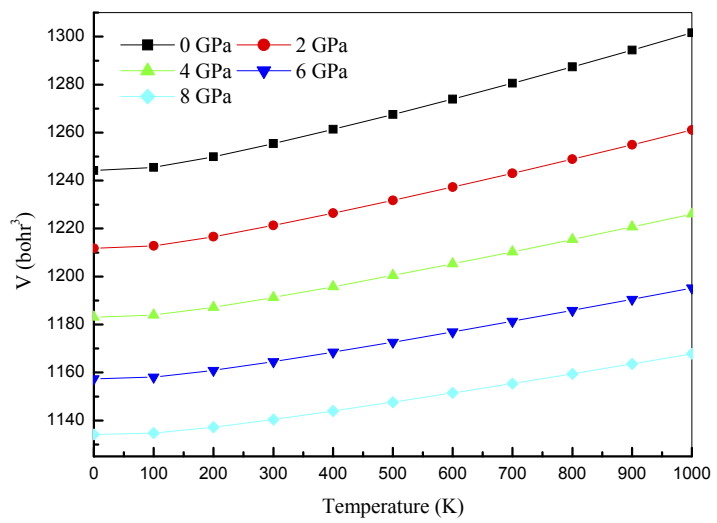

(a)

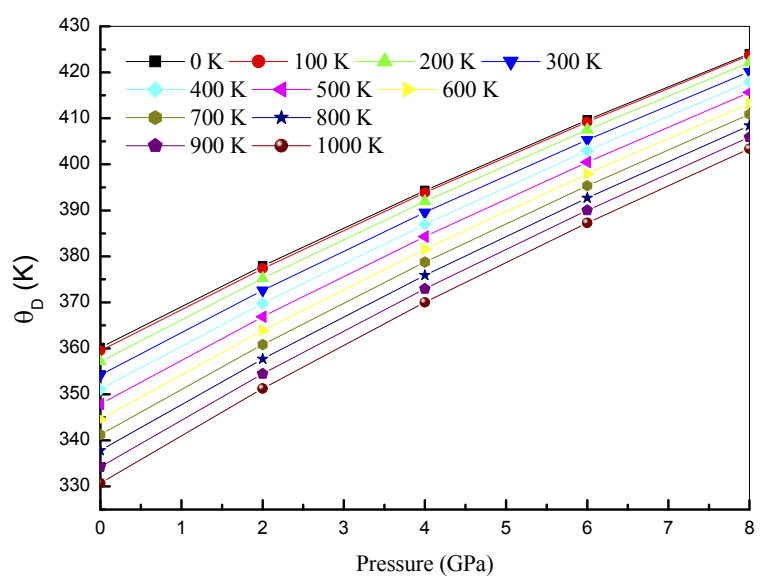

(c)

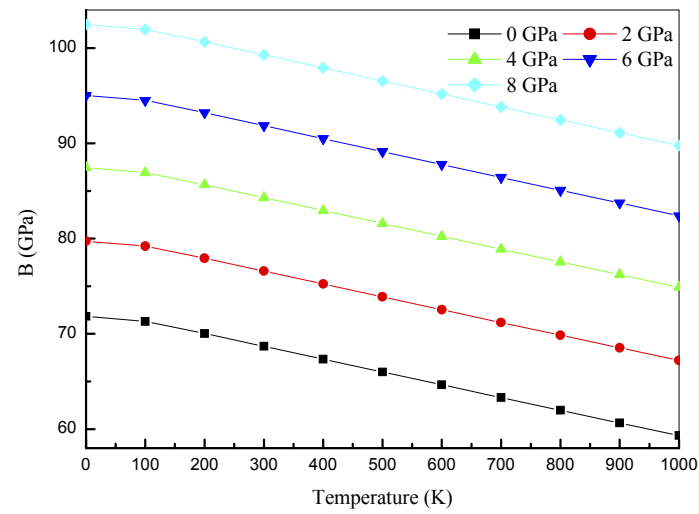

(b)

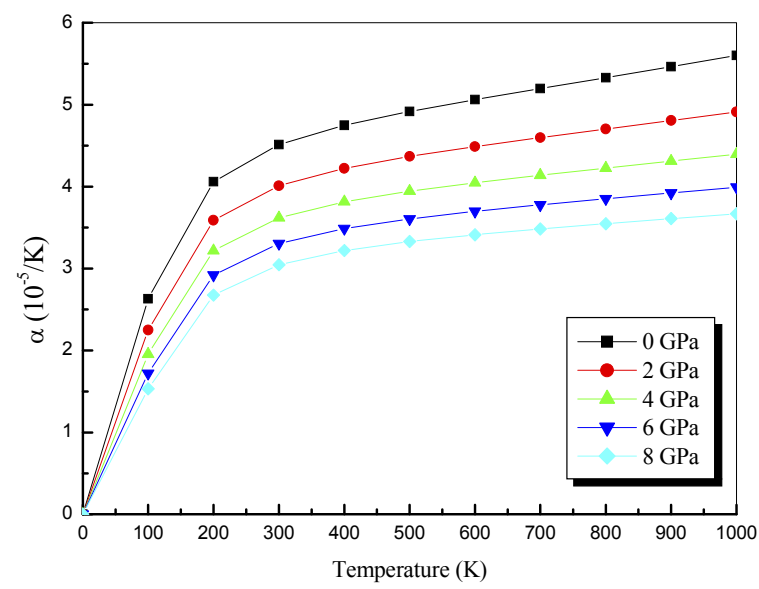

(d)

Figure 6. (a) Volume vs temperature at various pressures (b) Bulk modulus vs temperature at various pressures, (c) Debye temperature vs pressure at various temperatures (d) Thermal expansion coefficients vs temperature at various pressures for $\mathrm{ZnSnP}_{2}$.

To determine the thermodynamic properties through the quasi-harmonic Debye model, a temperature range $0 \mathrm{~K}-1000 \mathrm{~K}$ has been taken. The pressure effects are studied in the 0-8 GPa range. Figure 6 (a) presents relationships between the equilibrium volume $\mathrm{V}\left(\mathrm{bohr}^{3}\right)$ and pressure at various temperatures. Meanwhile, $\mathrm{V}$ increases slightly as the temperature increases, whereas the equilibrium volume $\mathrm{V}$ decreases dramatically as the pressure $\mathrm{P}$ increases at a given temperature. This account suggests that the $\mathrm{ZnSnP}_{2}$ under loads turns to be more compressible with increasing pressure than decreases temperature. Furthermore, it is noted that the relationship between the bulk modulus and temperature for $\mathrm{ZnSnP}_{2}$ in Figure 6 (b). The bulk modulus slightly decreases with increasing temperature at a given pressure and increases with increasing pressure at a given temperature. 
The variation of the Debye temperature $\theta_{\mathrm{D}}(\mathrm{K})$ of $\mathrm{ZnSnP}_{2}$ as a function of pressure and temperature illustrated by proposed results is displayed in Figure $6(\mathrm{c})$. With the applied pressure increasing, the Debye temperatures are almost linearly increasing. Figure $6(\mathrm{~d})$ shows the volume thermal expansion coefficient $\theta_{\mathrm{D}}\left(10^{-5} / \mathrm{K}\right)$ at various pressures, from which it can be seen that the volume thermal expansion coefficient $\theta_{D}$ increases quickly at a given temperature particularly at zero pressure below the temperature of $300 \mathrm{~K}$. After a sharp increase, the volume thermal expansion coefficient is nearly insensitive to the temperature above $300 \mathrm{~K}$ due to the electronic contributions.

As very important parameters, the heat capacities of a substance not only provide essential insight into the vibrational properties, but are also mandatory for many applications. The proposed calculation of the heat capacities $C_{P}$ and $C_{V}$ of $\mathrm{ZnSnP}_{2}$ verses temperature at pressure range 0-8 GPa is shown in Figure 7.
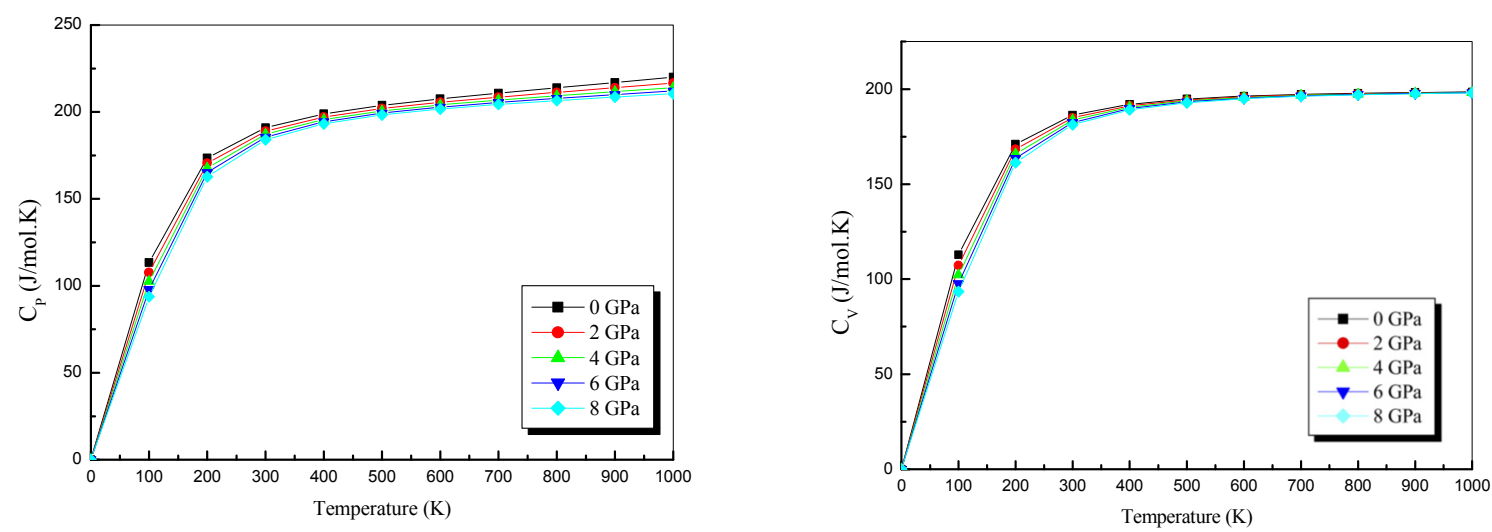

Figure 7. Heat capacities $\left(\mathrm{C}_{\mathrm{p}}\right.$ and $\left.\mathrm{C}_{\mathrm{v}}\right)$ vs temperature at various pressures for $\mathrm{ZnSnP}_{2}$

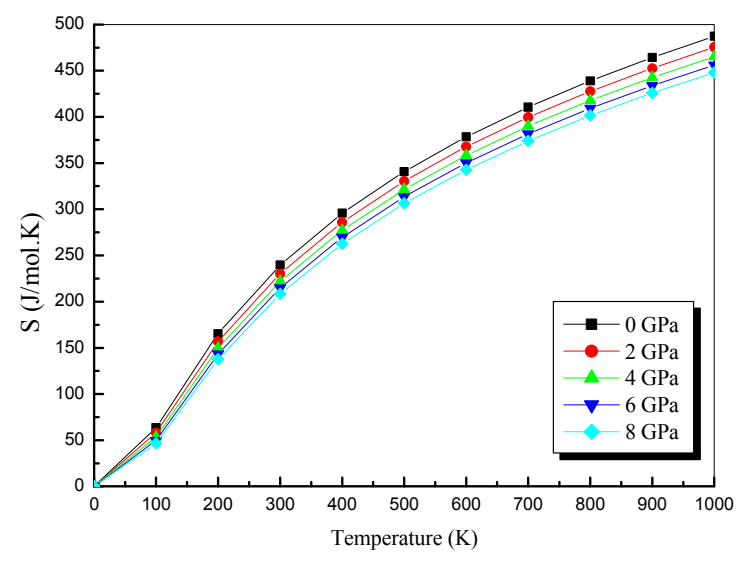

(a)

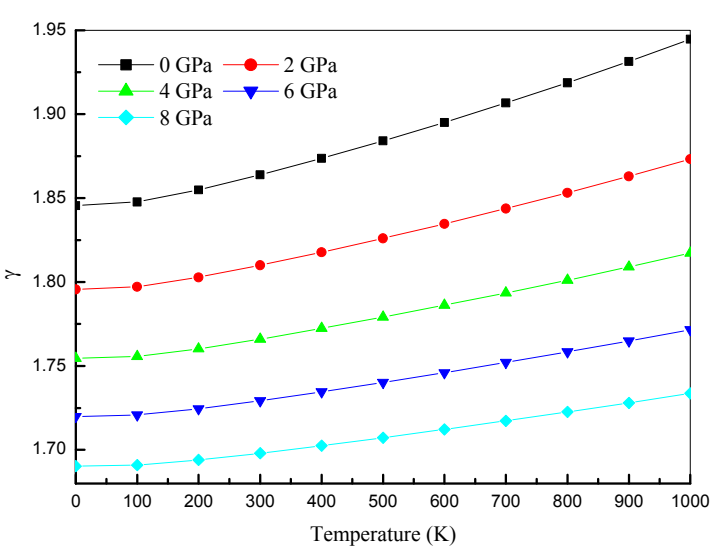

(b)

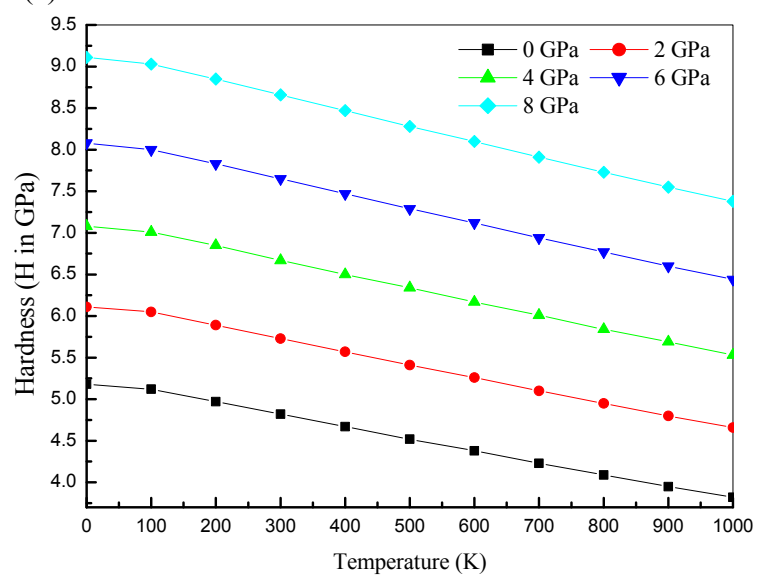

(c)

Figure 8. (a) Entropy vs temperature at various pressures, (b) Gruneisen parameter vs temperature at various pressures, (c) Hardness vs temperature at various pressures for $\mathrm{ZnSnP}_{2}$.

From these figures, we can see that the constant volume heat capacity $C_{V}$ and the constant pressure capacity $C_{P}$ are very similar in appearance and both of them are proportional to $\mathrm{T}^{3}$ at low temperatures. At high temperatures, the 
anharmonic effect on heat capacity is suppressed; which is called Dulong-Petit limit, with the increasing of the temperature, whereas $\mathrm{C}_{\mathrm{P}}$ increases monotonically with the temperature.

Figure 8 (a) shows the entropy vs temperature at various pressures. The entropies are variable by power exponent with increasing temperature but the entropies are higher at low pressure than that at high pressure at same temperature. The Grüneisen parameter $\gamma$ is another important quantity for the materials. In Figure 8 (b), we have shown the values of Grüneisen parameter $\gamma$ at different temperatures and pressures. It shows the value $\gamma$ increases as the temperature increases at a given pressure and decreases as the pressure increases at a given temperature.

In Figure $8(\mathrm{c})$, we have shown the values of hardness (H in GPa) at different temperatures and pressures. It shows the hardness decreases as the temperature increases at a given pressure and increases as the pressure increases at a given temperature. The values of hardness are reported for the first time at different pressure and temperature. Table 1 present the thermal properties such as isothermal bulk modulus, hardness, Grüneisen parameter, Debye temperature and thermal expansion coefficient at $300 \mathrm{~K}$.

\section{CELL STRUCTURE, MATERIAL PARAMETERS AND CELL PERFORMANCE}

The modeled cell structure is shown in Figure 9 (a). The simulated structure starts with $2500 \mathrm{~nm} \mathrm{ZnSnP}{ }_{2}$ layer over a Molybdenum substrate followed by $50 \mathrm{~nm} \mathrm{CdS/ZnTe} \mathrm{buffer} \mathrm{and} 50 \mathrm{~nm}$ intrinsic $\mathrm{ZnO}$ window layer with $300 \mathrm{~nm} \mathrm{Al}$ doped $\mathrm{ZnO}$ layer.

The device simulation is based on the solution of a set of equations, which provide a mathematical model for device operation. Using this model, the influence of the modeling parameters over the efficiency of the device can be examined, which is a tedious task by experimental method. The simulation is based on the solution of one-dimensional Poisson equation and the continuity equations for free charge carriers. These equations are expressed as follows:

$$
\begin{gathered}
\frac{d}{d x}\left(-\varepsilon(x) \frac{d \psi}{d x}\right)=q\left[p(x)-n(x)+N_{D}^{+}(x)-N_{A}^{-}(x)+p_{t}(x)-n_{t}(x)\right] \\
\frac{d p_{n}}{d t}=G_{p}-\frac{p_{n}-p_{n 0}}{\tau_{p}}-p_{n} \mu_{p} \frac{d E}{d x}-\mu_{p} E \frac{d p_{n}}{d x}+D_{p} \frac{d^{2} p_{n}}{d x^{2}} \\
\frac{d n_{p}}{d t}=G_{n}-\frac{n_{p}-n_{p 0}}{\tau_{n}}+n_{p} \mu_{n} \frac{d E}{d x}+\mu_{n} E \frac{d n_{p}}{d x}+D_{n} \frac{d^{2} n_{p}}{d x^{2}}
\end{gathered}
$$

Where $\varepsilon$ the permittivity, $\mathrm{q}$ the charge, $\Psi$ the electrostatic potential, $\mathrm{n}$ the free electron density, $\mathrm{p}$ the free hole density, $p_{t}(x)$ the trapped hole density, $n_{t}(x)$ the trapped electron density, $N_{D}{ }^{+}$the donor atom density, $N_{A}^{-}$the acceptor atom density, $\mathrm{E}$ the electric field and $\mathrm{G}$ the generation rate, $\mathrm{D}$ the diffusion coefficient, $\tau$ the lifetime and $\mu$ the mobility of charge carriers. With the help of solution of these equations current density/voltage $(\mathrm{J} / \mathrm{V})$ characteristics are determined and performance of solar cell with different buffer layers is compared. In Table 5 we have presented description for the parameters; which was used in the simulation. The terrestrial spectrum AM 1.5 (Air Mass 1.5 Global $1000 \mathrm{~W} / \mathrm{m}^{2}$ ) is used for illumination. The schematic energy band diagram under equilibrium condition for the thin layer

\begin{tabular}{|c|c|c|c|c|c|}
\hline $\begin{array}{ll}\text { Parameters } & \text { Layers } \\
\end{array}$ & $1-n+Z n O$ & $2-n(i) \mathrm{ZnO}$ & $3-C d S$ & $3-\mathrm{ZnTe}$ & $4-\mathrm{ZnSnP}_{2}$ \\
\hline Thickness (nm) & 300 & 50 & $50^{\mathrm{k}}$ & 50 & 2500 \\
\hline$\varepsilon$ (dielectric constant) & $9.26^{\mathrm{a}}$ & $9^{g, c}$ & $9.4^{\mathrm{a}}$ & $14^{\mathrm{m}}$ & $8.62 *$ \\
\hline$\mu_{\mathrm{n}}\left(\right.$ electron mobility in $\left.10 \mathrm{~cm}^{2} / \mathrm{Vs}\right)$ & $65.6^{\mathrm{b}}$ & $230^{\mathrm{h}}$ & $265^{1}$ & $70^{\mathrm{m}}$ & $55^{\mathrm{n}}$ \\
\hline$\mu_{\mathrm{p}}\left(\right.$ hole mobility in $\left.10 \mathrm{~cm}^{2} / \mathrm{Vs}\right)$ & $65^{\mathrm{c}}$ & $70^{i}$ & $15^{1}$ & $50^{\mathrm{m}}$ & $35^{\circ}$ \\
\hline$n / p\left(\right.$ carrier density in $\left.\mathrm{cm}^{-3}\right)$ & $1 \times 10^{21 \mathrm{c}}$ & $5 \times 10^{17 \mathrm{j}}$ & $1 \times 10^{17 \mathrm{j}}$ & $7.5 \times 10^{19 \mathrm{~m}}$ & $1 \times 10^{160}$ \\
\hline $\mathrm{E}_{\mathrm{g}}(\mathrm{eV})$ (optical band gap) & $3.228^{\mathrm{d}}$ & $3.29^{\mathrm{d}}$ & $2.42^{\mathrm{j}}$ & $2.25^{\mathrm{m}}$ & $1.9^{*}$ \\
\hline $\mathrm{N}_{\mathrm{c}}\left(\right.$ electron density in $\left.\mathrm{cm}^{-3}\right)$ & $1 \times 10^{19 \mathrm{e}}$ & $1 \times 10^{19 \mathrm{e}}$ & $1 \times 10^{19 \mathrm{e}}$ & $1 \times 10^{15 \mathrm{~m}}$ & $6.8 \times 10^{17}$ \\
\hline $\mathrm{N}_{\mathrm{v}}\left(\right.$ effective density in $\left.\mathrm{cm}^{-3}\right)$ & $1 \times 10^{19 \mathrm{e}}$ & $1 \times 10^{19 \mathrm{e}}$ & $1.6 \times 10^{19 \mathrm{e}}$ & $1.5 \times 10^{19 \mathrm{~m}}$ & $1.5 \times 10^{19}$ \\
\hline$\chi$ electron affinity $(\mathrm{eV})$ & $4.2^{\mathrm{f}}$ & $4.445^{\mathrm{j}}$ & $4.3^{\mathrm{e}}$ & $3.65^{\mathrm{m}}$ & $4 \cdot 25^{\mathrm{n}}$ \\
\hline
\end{tabular}
solar cell has been illustrated in Figure 9 (b).

Table 5. Material properties for the $\mathrm{ZnSnP}_{2}$ solar cells simulation.

${ }^{\mathrm{a}}$ Reference [55]; ${ }^{\mathrm{b}}$ Reference [56]; ${ }^{\mathrm{c}}$ Reference [57]; ${ }^{\mathrm{d}}$ Reference [58]; ${ }^{\mathrm{e}}$ Reference [59]; ${ }^{\mathrm{f}}$ Reference [60]; ${ }^{\mathrm{g}}$ Reference [61]; ${ }^{\mathrm{h}}$

Reference [62]; ${ }^{\mathrm{i}}$ Reference [63]; ${ }^{\mathrm{j}}$ Reference [64]; ${ }^{\mathrm{k}}$ Reference [65]; ${ }^{\prime}$ Reference [66]; ${ }^{\mathrm{m}}$ Reference [67]; ${ }^{\mathrm{n}}$ Reference [68]; ${ }^{\circ}$ Reference [69]; "This work

The band diagram is drawn according to Anderson's affinity rule, which shows conduction band offset is $\Delta \mathrm{E}_{\mathrm{c}}=\chi_{2}-\chi_{1}$ and valance band offset is $\Delta \mathrm{E}_{\mathrm{c}}=\left(\chi_{1}+\mathrm{E}_{\mathrm{g} 1}\right)-\left(\chi_{2}+\mathrm{E}_{\mathrm{g} 2}\right)$. The band diagram shows that this is a type II heterostructure. The difference in band gaps creates discontinuity spikes in the conduction- and valence bands [45]. These 
spikes can create extra barriers for the electrons to overcome or tunnel through, and may also work as potential wells with discrete energy states [46].

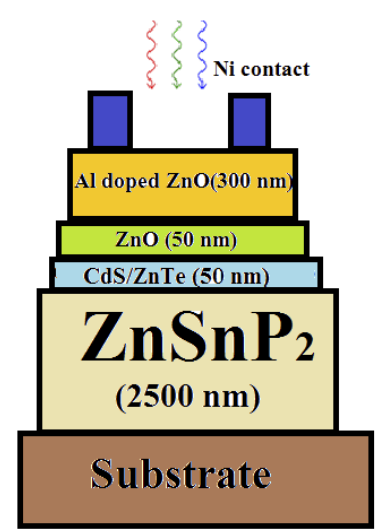

Figure 9 (a). The layer structure of $\mathrm{ZnSnP}_{2}$ solar cell.

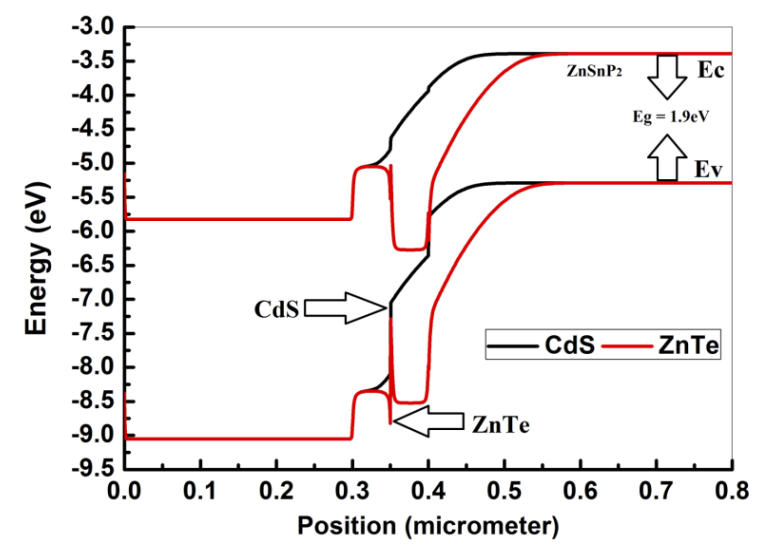

Figure 9 (b). The schematic energy-band diagram of a typical $\mathrm{ZnSnP}_{2} / \mathrm{CdS}$ or $\mathrm{ZnTe}$ solar cell under equilibrium condition.

The Figure 9 (c) shows the illuminated characteristics $J$ - $V$ curve of the proposed solar cell structures. The performance parameters open circuit voltage $\left(V_{\mathrm{oc}}\right)$, short circuit current density $\left(J_{\mathrm{sc}}\right)$, Fill Factor $(F F)$ and efficiency $(\eta)$ have been calculated from $J-V$ characteristics for different considered buffer layers. The simulation results have been presented in Table 6 . These results show that both the buffer layers provide good efficiency ( $>20 \%$ ); but the fill factor for ZnTe buffer layer is considerably high. A maximum density of current $\left(>29 \mathrm{~mA} / \mathrm{cm}^{2}\right)$ has been obtained with both the buffer layers, which ensures the suitability of $\mathrm{CdS}$ and $\mathrm{ZnTe}$ buffer layers in $\mathrm{ZnSnP}_{2}$ solar cells.

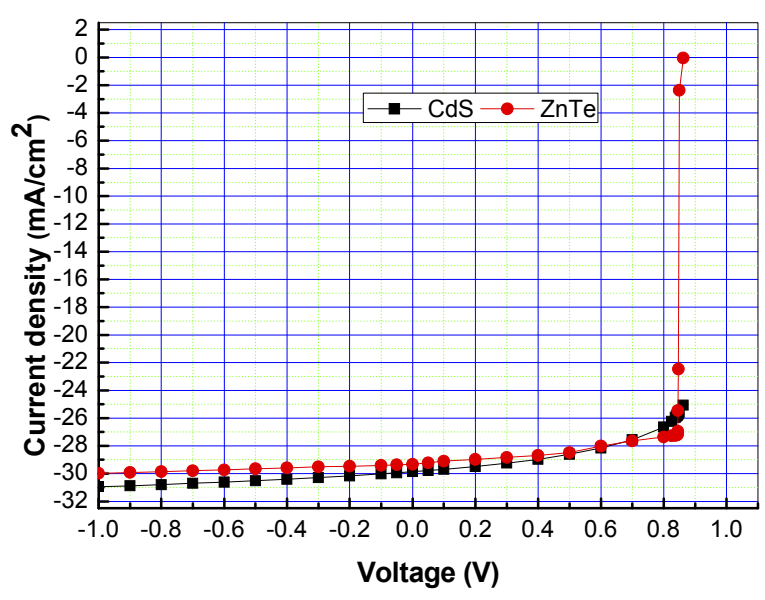

Figure 9 (c). Photo-current density-voltage (J-V) curves for the simulated results for $50 \mathrm{~nm}$ thickness of buffer layers.

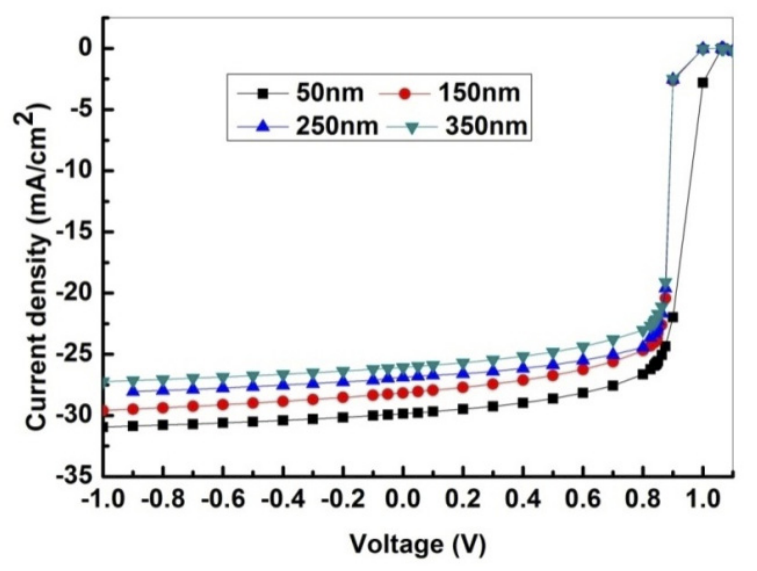

Figure 9 (e). Effect of thickness of buffer layer over J-V characteristics of $\mathrm{ZnSnP}_{2} / \mathrm{CdS}$ solar cell.

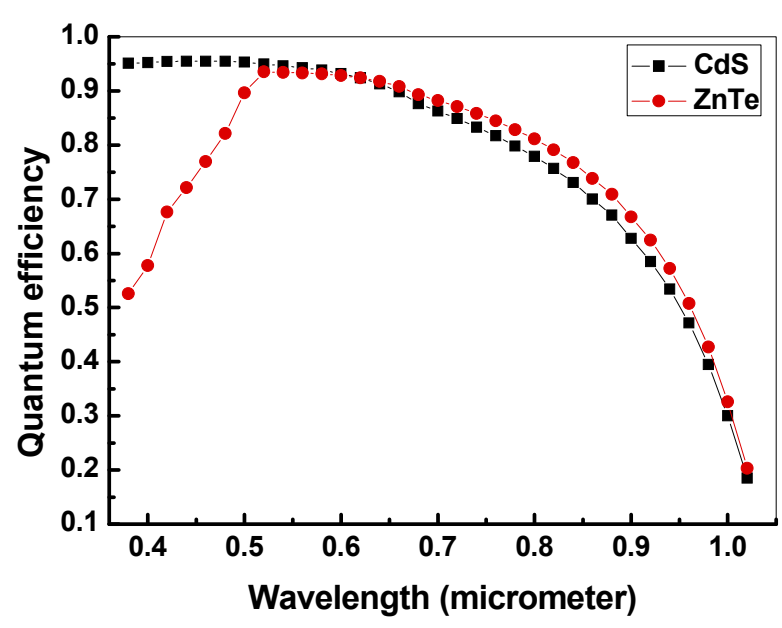

Figure 9 (d). Quantum efficiency curves for $\mathrm{ZnSnP}_{2} / \mathrm{CdS}$ or $\mathrm{ZnTe}$ solar cell for $50 \mathrm{~nm}$ thickness of buffer layer

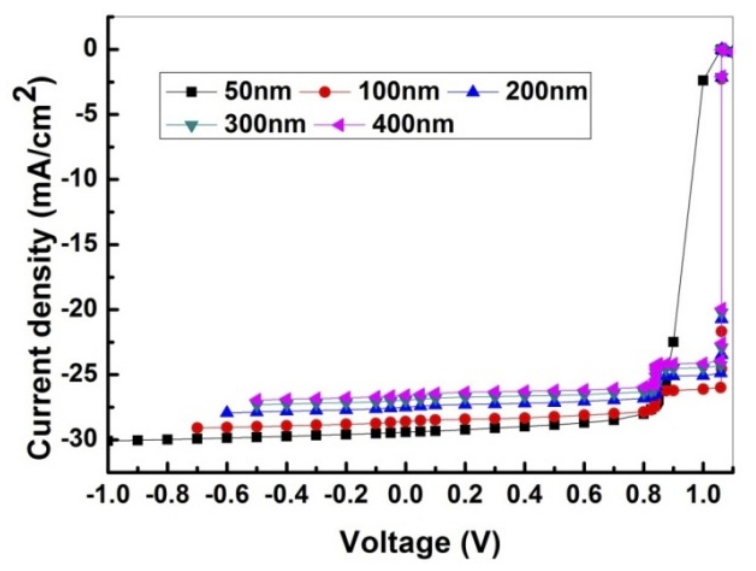

Figure 9 (f). Effect of thickness of buffer layer over J-V characteristics of $\mathrm{ZnSnP}_{2} / \mathrm{ZnTe}$ solar cell. 
Table 6. Simulated performance parameters of the solar cells for absorption layer $\mathrm{ZnSnP}_{2}$

\begin{tabular}{|l|l|l|l|l|l|}
\hline Buffer layer & $\mathrm{E}_{\mathrm{g}}$ & $(\%)$ & $V_{\mathrm{oc}}(\mathrm{mV})$ & $J_{\mathrm{sc}}\left(\mathrm{mA} / \mathrm{cm}^{2}\right)$ & $F F(\%)$ \\
\hline CdS & 1.06 & 13.186 & 604 & 29.235 & 74.6 \\
\hline & 1.9 & 21.748 & 1066 & 29.864 & 68.3 \\
\hline ZnTe & 1.06 & 14.055 & 603 & 29.121 & 80.1 \\
\hline & 1.9 & 22.926 & 1062 & 29.415 & 73.4 \\
\hline
\end{tabular}

Further, the analysis of photoconductivity of cell structure is done in terms of quantum efficiency (QE) as shown in Figure 9 (d). The spectral response of the device is studied within the spectral range of $0.4 \mu \mathrm{m}$ to $1.0 \mu \mathrm{m}$. Quantum efficiency is a measure of collection of charge carriers with respect to number of incident photons. As CdS buffer layer has higher band gap, it provides a wider window for absorption of photons, thus creating larger number of charge carriers and resulting in higher quantum efficiency in lower wavelength region, whereas in higher wavelength region $\mathrm{QE}$ of CdS becomes lower which ensures higher recombination in this structure. The higher values of quantum efficiencies are found for blue region of the light. Since blue light is absorbed closer to the junction, recombination effect is less effective for this wavelength region whereas at higher side of wavelength high recombination occurs, since the free carrier generated deeper in the bulk have to travel longer before being collected. This results higher recombination loss and in tern lower quantum efficiency in long wavelength region. Moreover, the absorption coefficient decreases with the increasing of the photon wavelength, so the loss in absorption causes the spectral response to decrease quickly and thus the quantum efficiency.

\section{Effect of buffer layer thickness}

The effect of thickness of buffer layer on J-V characteristics for the two cell structures are shown in Figures 9 (e)-9 (f). With the help of these characteristics $J_{s c}, V_{o c}, \eta$ and FF are calculated at different thickness of buffer layers. The effect of thickness of buffer layer over performance parameters of these cell structures is shown in Figures 10 (a)-10 (c).

Figure 10 (a) and 10 (b) shows that as thickness of buffer layer increases, the current density as well as efficiency start to decrease for both the structures. This shows that at $50 \mathrm{~nm}$ the ratio of diffusion length to the thickness of the buffer layer is appropriate for collection of minority carriers. After this thickness all the photogenerated carriers are not able to reach the depletion region, which in turn decreases the current density and efficiency. The decrement in current density at lower thickness values is fast in $\mathrm{ZnSnP}_{2} / \mathrm{CdS}$ structure, which shows that rate of recombination is higher in $\mathrm{ZnSnP} / \mathrm{CdS}$ solar cell structure.

Further, the effect of thickness over open circuit voltage for all the three buffer layers is shown in Figure 10 (c). At $50 \mathrm{~nm}$ thickness a significant value of $V_{o c}$ is found whereas for higher values of thickness it decreases for both the structures. At higher thickness the separated charge carriers starts to recombine before reaching the electrodes, which causes decrement in $V_{o c}$.

Effect of thickness over fill factor for the two structures is shown in Figure 10 (d). It is a measure of maximum power that can be achieved by a cell. As both the structures are showing the highest FF at 50nm thickness, ensures that at lower values of thickness charge collection is good because charge carriers are able to reach the electrodes. After this thickness charge collection suffers due to low values of diffusion length than the thickness of buffer layer. Further, with increment in thickness FF becomes almost constant because maximum effect of recombination over charge collection is achieved.

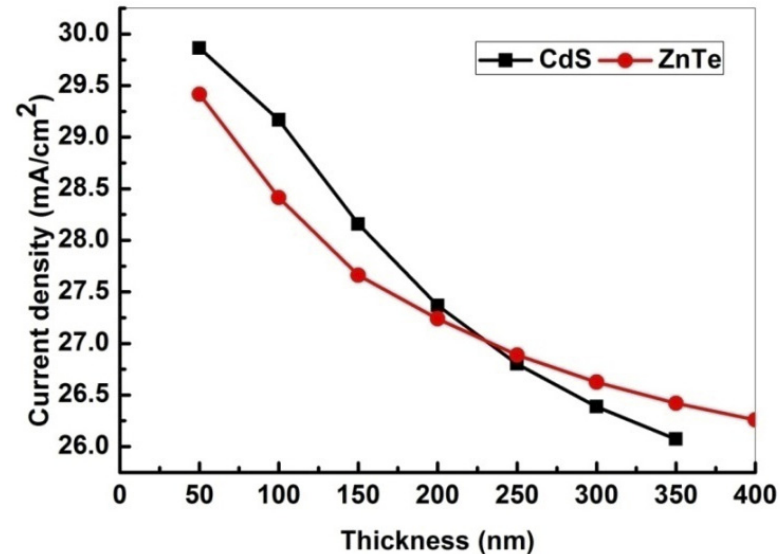

Figure 10 (a). Effect of thickness of buffer layer over current density of $\mathrm{ZnSnP}_{2} / \mathrm{CdS}$ or $\mathrm{ZnTe}$ solar cell.

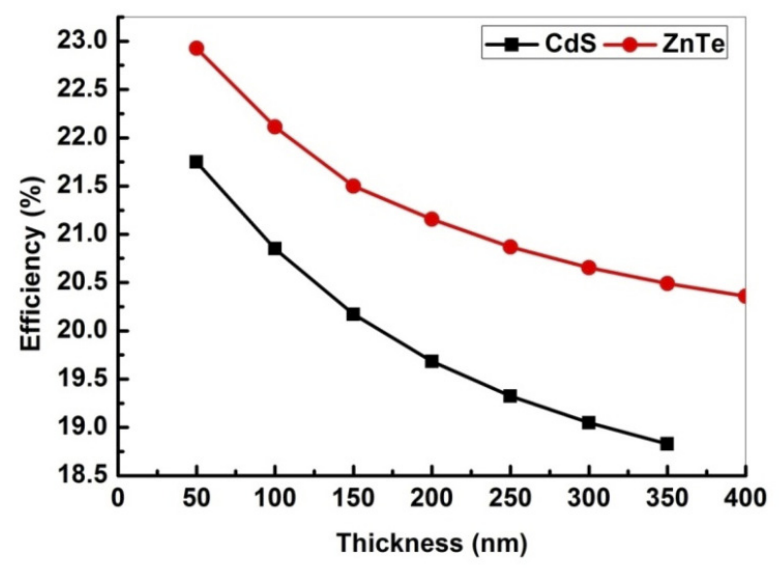

Figure 10 (b). Effect of thickness of buffer layer over efficiency of $\mathrm{ZnSnP}_{2} / \mathrm{CdS}$ or $\mathrm{ZnTe}$ solar cell. 


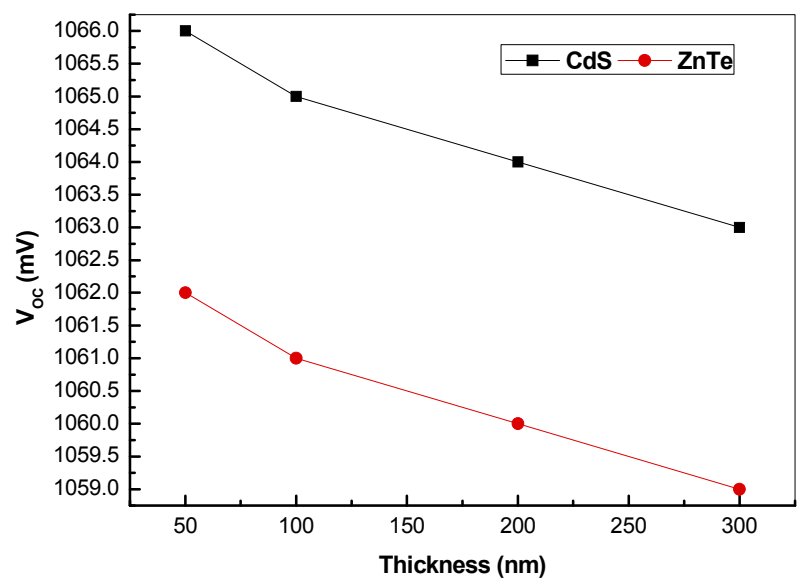

Figure 10 (c). Effect of thickness of buffer layer over $\mathrm{V}_{\text {oc }}$ of $\mathrm{ZnSnP}_{2} \mathrm{ZnSnP}_{2} / \mathrm{CdS}$ or $\mathrm{ZnTe}$ solar cell.

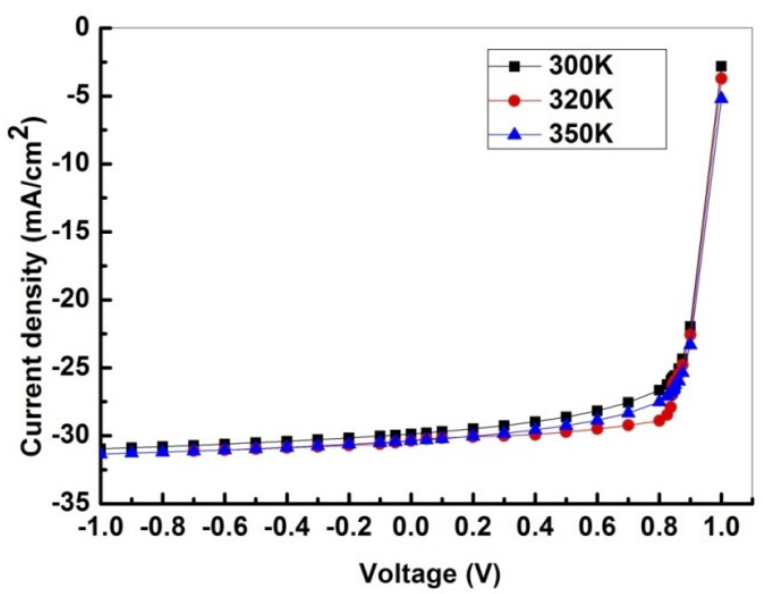

Figure 10 (e). Effect of temperature over J-V characteristics of $\mathrm{ZnSnP}_{2} / \mathrm{CdS}$ solar cell.

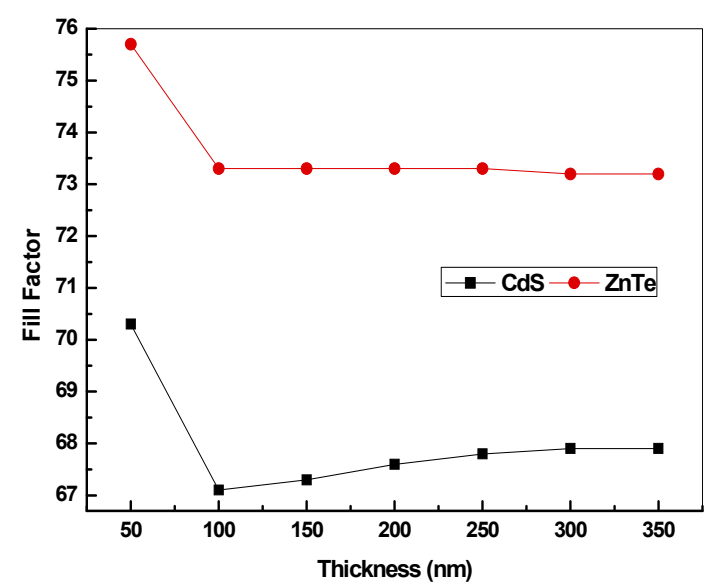

Figure 10 (d). Effect of thickness of buffer layer over fill factor of $\mathrm{ZnSnP}_{2} / \mathrm{CdS}$ or $\mathrm{ZnTe}$ solar cell

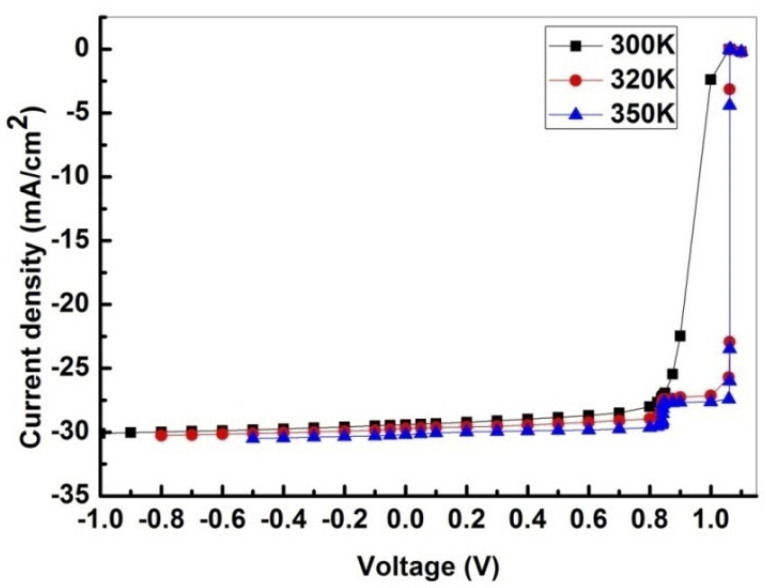

Figure 10 (f). Effect of temperature over J-V characteristics of $\mathrm{ZnSnP}_{2} / \mathrm{ZnTe}$ solar cell.

Effect of temperature

The effect of temperature over J-V characteristics for both the three structures is shown in Figure 10 (e) and 10 (f). Further, Figures 11(a)-11(e) shows the effect of temperature over performance parameters for the two cell structures.

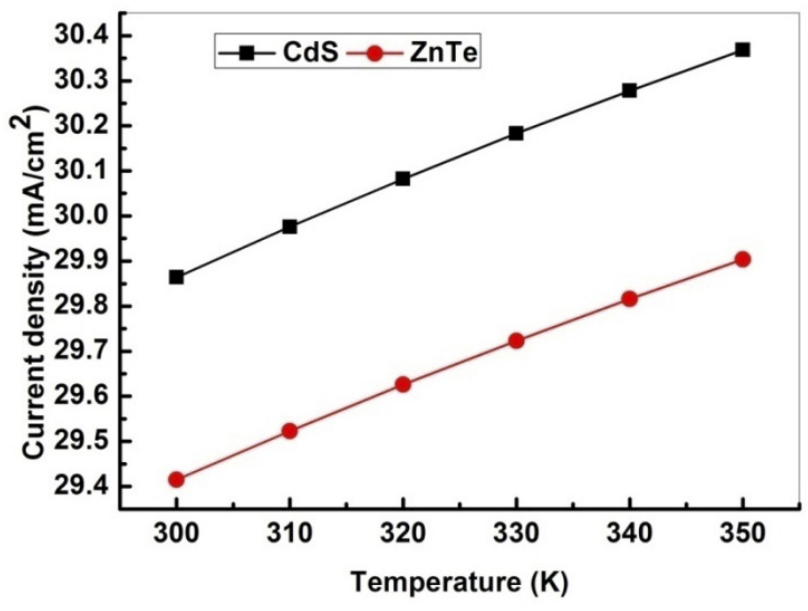

Figure 11 (a). Effect of temperature over current density of $\mathrm{ZnSnP}_{2} / \mathrm{CdS}$ or $\mathrm{ZnTe}$ solar cell structures.

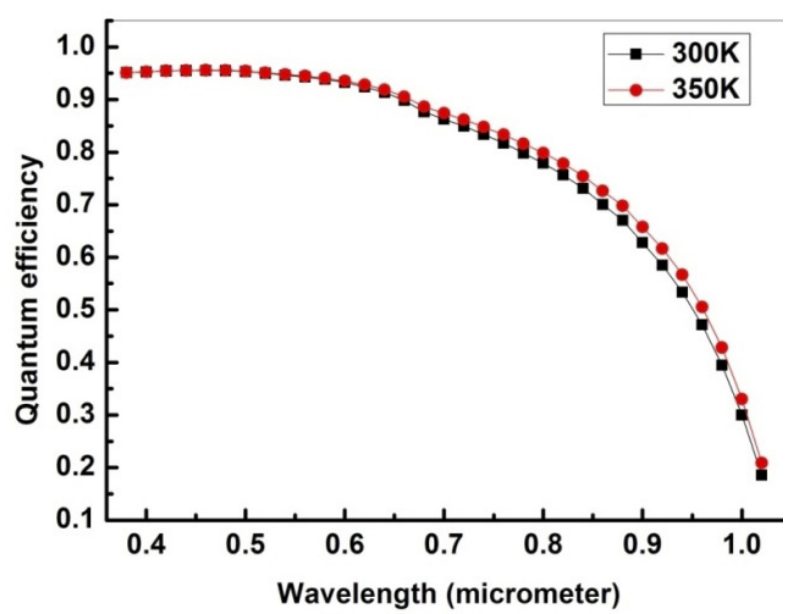

Figure 11 (b). Effect of temperature over quantum efficiency of $\mathrm{ZnSnP} / \mathrm{CdS}$ solar cell. 


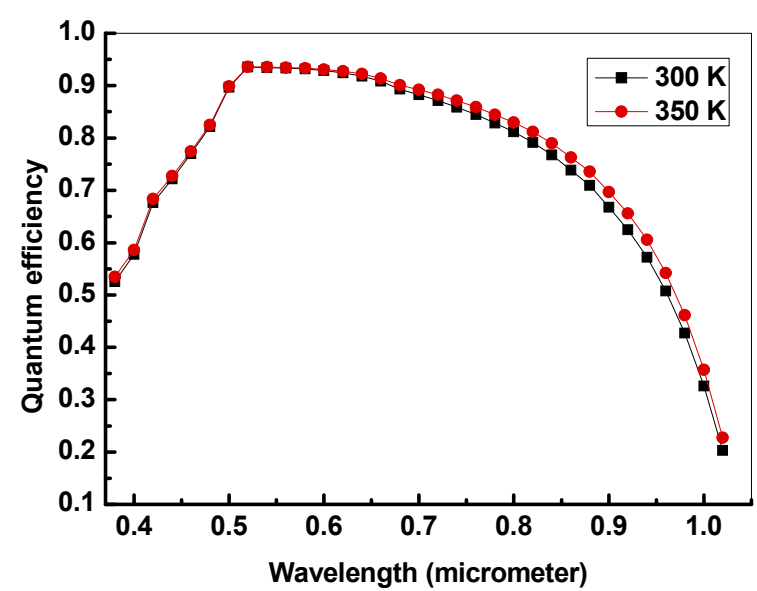

Figure 11 (c). Effect of temperature over quantum efficiency of $\mathrm{ZnSnP}_{2} / \mathrm{ZnTe}$ solar cell.

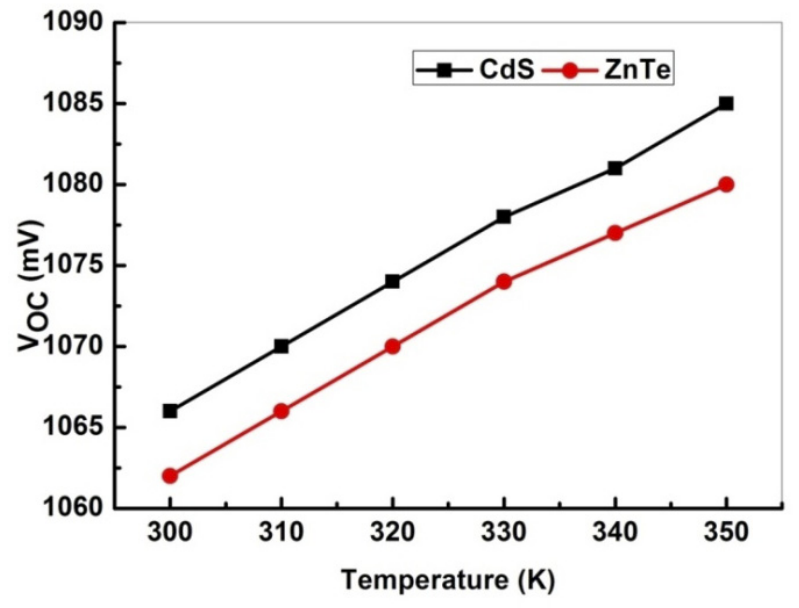

Figure 11 (d). Effect of temperature over open circuit voltage of $\mathrm{ZnSnP} 2 / \mathrm{CdS}$ or $\mathrm{ZnTe}$ solar cell structures.

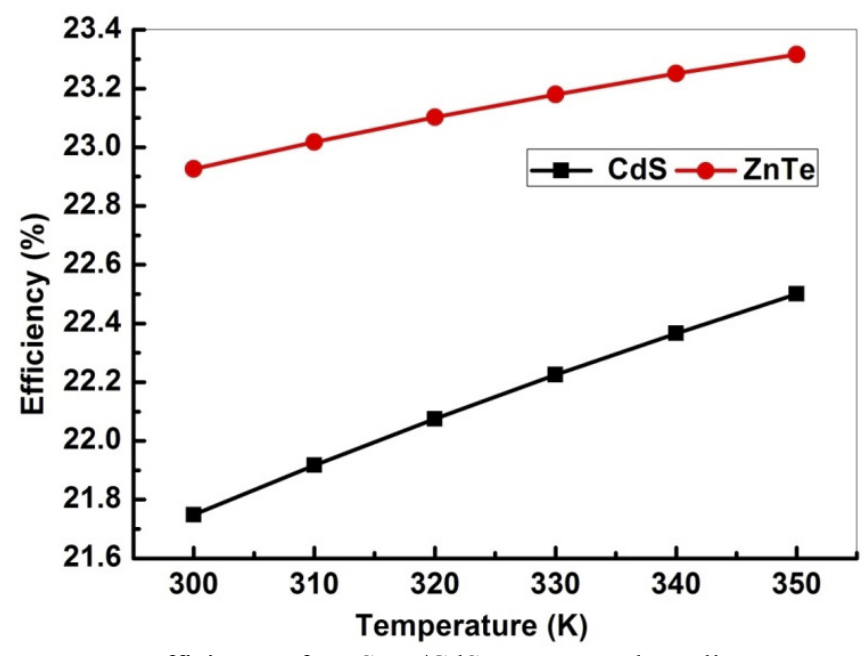

Figure 11 (e). Effect of temperature over efficiency of $\mathrm{ZnSnP}_{2} / \mathrm{CdS}$ or $\mathrm{ZnTe}$ solar cell structures.

In Figure 11 (a), $J_{s c}$ increases with temperature for both the structures considered. This effect can be understood in terms of band gap. The effect of temperature over energy band gap, $\mathrm{E}_{\mathrm{g}}$ is given by Varshni equation [47]

$$
E_{g}(T)=E_{g}(0)-\frac{\alpha T^{2}}{T+\beta}
$$

Where $\mathrm{E}_{\mathrm{g}}(0)$ is the band gap energy at absolute zero on the Kelvin scale in the given material, and $\alpha$ and $\beta$ are material-specific constants. This decrement in band gap is responsible for enhancement in current density values at higher temperature. Increase in temperature can be viewed as increase the energy of the charge carriers. Thus less energy is required to break the bond and conduction increases.

As a consequence of the increase in temperature, there is a shift in quantum efficiency curves (Figure 11(b),11(c)). When the temperature of the cell is increased, thermal vibrations of the lattice becomes stronger, which causes reduction in lifetime and mobility of minority charge carriers. This in turn reduces the diffusion length and process of recombination becomes stronger. But with increase in temperature, the band gap is reduced, which enhances the production of charge carriers. In low and middle temperature range, there is equilibrium in between the phenomenon of charge generation and recombination.

But with temperature, the absorption in wide band gap materials is improved for long wavelength region because of the phonons multiplication phenomenon [48]. So, the minority carriers production is increased with temperature in the range of long wavelengths, thus the photocurrent increases and consequently, the quantum efficiency. Further with temperature a sharp increment is found in $V_{o c}$ (Figure $11(\mathrm{~d})$ ).

The effect over $V_{o c}$ can be understood as a measure of the amount of recombination in the device. As the temperature increases, the number of thermally generated carriers can exceed the number of dopant-generated carriers. Though the concentration of intrinsic carriers is very small; but it has very strong temperature dependence [49]. This increment in intrinsic carrier concentration causes the increase in reverse saturation current. The increment in reverse saturation current is responsible for decrement in open circuit voltage values. 
Also, the temperature dependence of $V_{O c}$ is given by [50]

$$
\frac{d V_{o c}}{d T} \approx \frac{d E_{g} / q}{d T}+\frac{V_{o c}-E_{g} / q}{T}
$$

From eq. (28) it is inferred that the temperature dependence is mainly related to the term $\frac{V_{o c}-E_{g} / q}{T}$; which after integration provides a linear relationship $V_{o} c \propto-T$ as observed experimentally [50].

Therefore, the tendency of $V_{o c}$ to decrease and $J_{s c}$ to increase with increasing temperature in the solar cells are determining factor for efficiency with variation in temperature. The overall effect of temperature has been studied for $\eta$ as shown in figure $11(\mathrm{e})$.

\section{Effect of Band gap of absorption layer}

The effect of band gap of absorption layer over performance parameters is studied. To find the effect of band gap, the results of $\mathrm{ZnSnP}_{2}$ absorption layer with band gap $1.06 \mathrm{eV}$ and $1.9 \mathrm{eV}$ are compared. The effect of band gap of absorption layer over J-V characteristics of the cell are shown in Figure 12 (a)-12 (d). These results show that the increment in band gap results in an increment in absorption of light, thus an increment in performance parameters is found (Table 6). This improvement in parameters is due to the enhancement of absorption in longer wavelength region. This effect can be seen in quantum efficiency curves in Figure 12 (c) and 12 (d).

Hence, the study shows that $\mathrm{ZnSnP}_{2}$ as absorption layer with $\mathrm{CdS}$ and $\mathrm{ZnTe}$ buffer can be promising solar cell model. ZnTe can be used as an option for CdS buffer layer, which is not only beneficial on the energy basis, but also helps in overcoming the serious environmental related problems due to the toxic nature of cadmium.

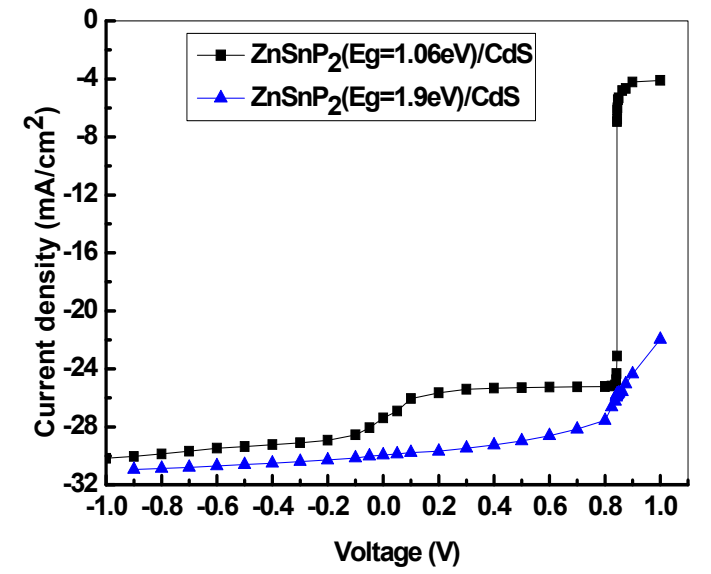

Figure 12 (a). Effect of band gap of absorption layer over J-V curves of $\mathrm{ZnSnP}_{2} / \mathrm{CdS}$ solar cell.

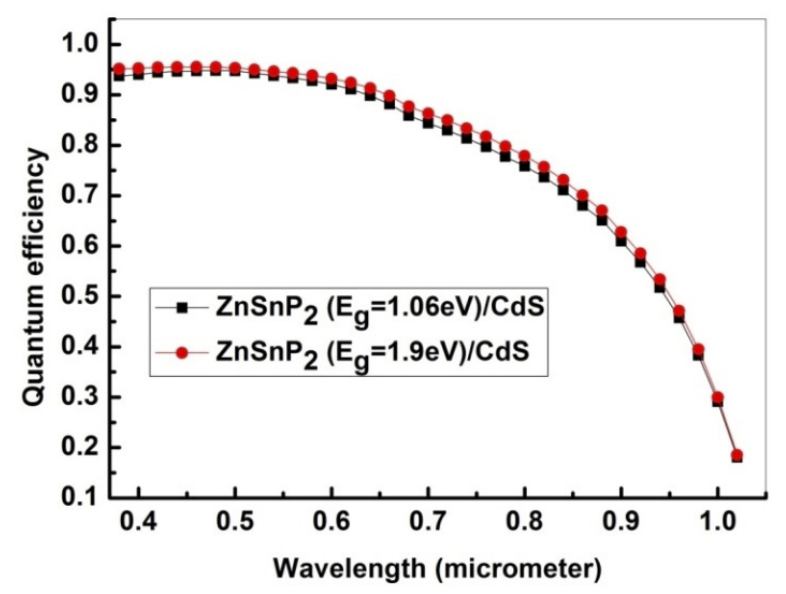

Figure 12 (c): Effect of band gap of absorption layer over quantum efficiency of $\mathrm{ZnSnP}_{2} / \mathrm{CdS}$ solar cell.

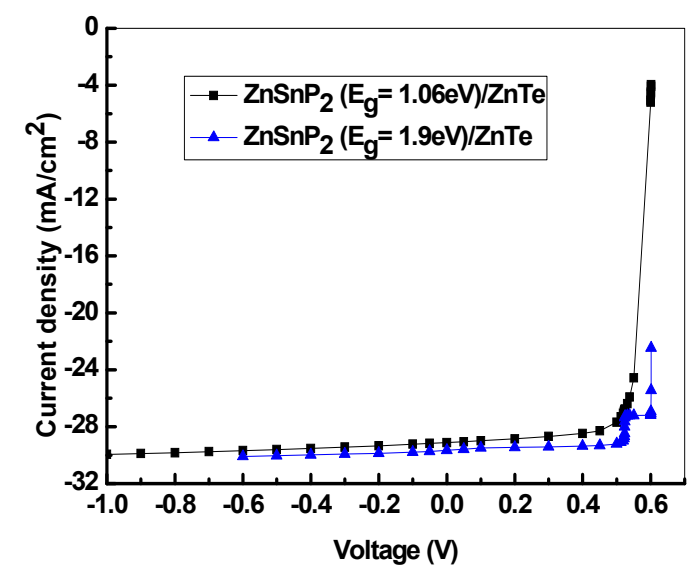

Figure 12 (b). Effect of band gap of absorption layer over J-V curves of $\mathrm{ZnSnP}_{2} / \mathrm{ZnTe}$ solar cell.

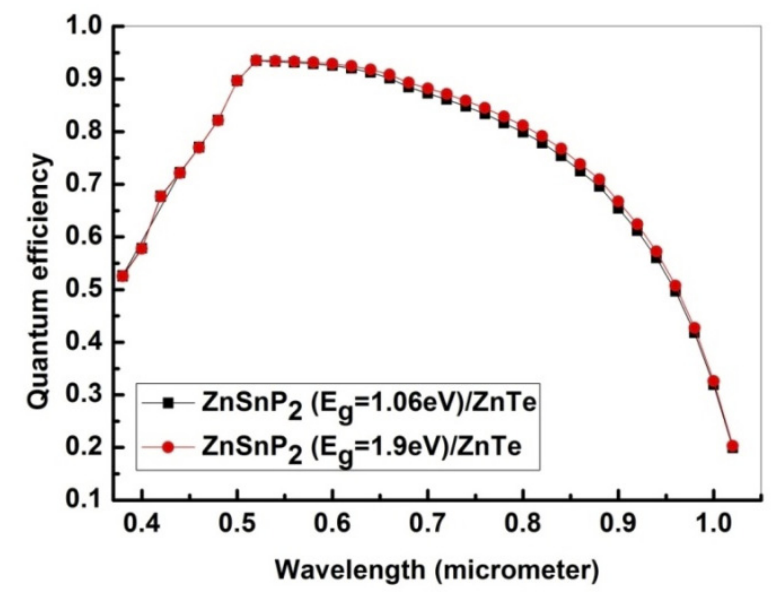

Figure 12 (d): Effect of band gap of absorption layer over quantum efficiency of $\mathrm{ZnSnP}_{2} / \mathrm{ZnTe}$ solar cell.

\section{SUMMARY AND CONCLUSIONS}

To conclude, results have been presented for the solid state properties such as structural, electronic, optical, elastic and thermal properties of the $\mathrm{ZnSnP}_{2}$ semiconductor using the first-principles calculation. The structural properties in the 
chalcopyrite structure are obtained using the total energy as a function of volume; the derived equilibrium parameters are compared with experimental data. We compared electronic and optical properties calculated with the mBJ functional and spectroscopic ellipsometry data. We find that the $\mathrm{mBJ}$ functional provides an accurate description of the electronic and optical properties. The $\mathrm{ZnSnP}_{2}$ has a direct band gap. We have also derived the static refractive index. Thermal properties such as Gruneisen parameter, volume expansion coefficient, bulk modulus, specific heat, entropy, debye temperature and hardness are calculated successfully at various temperatures and pressures, and trends are discussed. The ground state parameters of interest were obtained and showed good agreement with published experimental and theoretical data. An application of the material in solar cell device has been presented; here we have used AMPS-1D to investigate the dependence of the buffer layer for thin layer $\mathrm{ZnSnP}_{2}$ solar cells. A device modelling and detailed simulation study have been carried out over single junction $\mathrm{ZnSnP}_{2}$ solar cell with a variety of buffer layers. The performance parameters of solar cells as open-circuit voltage $\left(\mathrm{V}_{\mathrm{oc}}\right)$, the short-circuit current density (Jsc), the conversion efficiency $\eta$, Fill factor (FF) and quantum efficiency (QE) have been calculated. Also the effect of temperature and band gap of absorption layer is studied and it is found that higher band gap of absorption layer improves the performance of solar cell. Thus the study shows that $\mathrm{ZnTe}$ can be considered as an alternative to CdS buffer layer and assumes greater significance under this scenario. To the best of our knowledge, most of the investigated parameters are reported for the first time and will further stimulate the research in the related field.

\section{ORCID IDs}

(D)Neeraj, https://orcid.org/0000-0001-9205-3246; Did Ajay Singh Verma, https://orcid.org/0000-0001-8223-7658

\section{REFERENCES}

[1] S. Mukherjee, T. Maitra, A. Nayak, A. Pradhan, M. K. Mukhopadhyay, B. Satpati, and S. Bhunia, Materials Chemistry and Physics 204, 147-153 (2018), https://doi.org/10.1016/j.matchemphys.2017.10.014.

[2] S. Sharma, and A.S. Verma, Eur. Phys. J. B, 87, 159 (2014), https://doi.org/10.1140/epjb/e2014-41097-2.

[3] S. Sahin, Y.O. Ciftci, K. Colakoglu and N. Korozlu, J. Alloy. Comp. 529, 1-7 (2012), https://doi.org/10.1016/j.jallcom.2012.03.046.

[4] A.D. Martinez, E.L. Warren, P. Gorai, K.A. Borup, D. Kuciauskas, P.C. Dippo, and S.W. Boettcher, Energy \& Environmental Science, 9, 1031-1041 (2016), https://doi.org/10.1039/C5EE02884A.

[5] A.D. Martinez, A.N. Fioretti, E.S. Toberer, and A.C. Tamboli, J. Materials Chemistry A, 5, 11418-11435 (2017), https://doi.org/10.1039/C7TA00406K.

[6] K. Miyauchi, T. Minemura, K. Nakatani, H. Nakanishi, M. Sugiyama, and S. Shirakata, Phys. Stat. Sol. C, 6, 1116 (2009), https://doi.org/10.1002/pssc.200881170.

[7] S. Nakatsuka, S. Akari, J. Chantana, T. Minemoto, and Y. Nose, ACS Applied Materials \& Interfaces, 9, 33827-33832 (2017), https://doi.org/10.1021/acsami.7b08852.

[8] S. Nakatsuka, N. Yuzawa, J. Chantana, T. Minemoto, and Y. Nose, Physica Status Solidi A, 214, 1600650 (2017), https://doi.org/10.1002/pssa.201600650.

[9] D.O. Scanlon, and A. Walsh, Appl. Phys. Letts. 100, 251911 (2012), https://doi.org/10.1063/1.4730375.

[10] P.C. Sreeparvathy, V. Kanchana, and G. Vaitheeswaran, J. Appl. Phys, 119, 085701 (2016), https://doi.org/10.1063/1.4942011.

[11] A.S. Verma, Mat. Chem. Phys. 139, 256 (2013), https://doi.org/10.1016/j.matchemphys.2013.01.032.

[12] N. Yuzawa, J. Chantana, S. Nakatsuka, Y. Nose, and T. Minemoto, Curr. Appl. Phys. 17, 557-564 (2017), https://doi.org/10.1016/j.cap.2017.02.005.

[13] Y. Zhang, Comp. Mat. Sci. 133, 152-158 (2017), https://doi.org/10.1016/j.commatsci.2017.03.016.

[14] G.K.H. Madsen, P. Blaha, K. Schwarz, E. Sjöstedt, and L. Nordström, Phys. Rev. B, 64, 195134 (2001), https://doi.org/10.1103/PhysRevB.64.195134.

[15] K. Schwarz, P. Blaha, and G.K.H Madsen, Comput. Phys. Commun. 147, 71 (2002), https://doi.org/10.1016/S0010-4655(02)00206-0.

[16] P. Blaha, K. Schwarz, G.K.H. Madsen, D. Kvasnicka, and J. Luitz, in: WIEN2K, An Augmented Plane Wave Plus Local Orbitals Program for Calculating Crystal Properties, edited by K. Schwarz (Techn. Universität Wien, Austria, 2001).

[17] Z. Wu, and R.E. Cohen, Phys. Rev. B, 73, 235116 (2006), https://doi.org/10.1103/PhysRevB.73.235116.

[18] F. Tran, R. Laskowski, P. Blaha, and K. Schwarz, Phys. Rev. B, 75, 115131 (2007), https://doi.org/10.1103/PhysRevB.75.115131.

[19] W. Kohn, and L.J. Sham, Phys. Rev. 140, A1133 (1965), https://doi.org/10.1103/PhysRev.140.A1133.

[20] J.P. Perdew, K. Burke, and M. Ernzerhof, Phys. Rev. Lett. 77, 3865 (1996), https://doi.org/10.1103/PhysRevLett.77.3865.

[21] F. Tran and P. Blaha, Phys. Rev. Letts. 102, 226401 (2009), https://doi.org/10.1103/PhysRevLett.102.226401.

[22] P.E. Blochl, O. Jepsen, and O.K. Andersen, Phys. Rev. B, 49, 16223 (1994), https://doi.org/10.1103/PhysRevB.49.16223.

[23] F.D. Murnaghan, Proc. Natl. Acad. Sci. USA 30, 244-247 (1947), https://doi.org/10.1073/pnas.30.9.244.

[24] V.L. Shaposhnikov, A.V. Krivosheeva, V.E. Borisenko, J.L. Lazzari, and F.A. Avitaya, Phys. Rev. B, 85, 205201 (2012), https://doi.org/10.1103/PhysRevB.85.205201.

[25] J. Sun, H.T. Wang, N.B. Ming, J. He, and Y. Tian, Appl. Phys. Letts. 84, 4544 (2004), https://doi.org/10.1063/1.1758781.

[26] S. Saha, and T.P. Sinha, Phys. Rev. B, 62, 8828 (2000), https://doi.org/10.1103/PhysRevB.62.8828.

[27] P.Y. Yu, and M. Cardona, Fundamentals of Semiconductors, (Springer-Verlag, Berlin, 1996).

[28] M.Q. Cai, Z. Yin, and M.S. Zhang, Appl. Phys. Letts, 83, 2805 (2003), https://doi.org/10.1063/1.1616631.

[29] S. Sharma, A.S. Verma, R. Bhandari, S. Kumari, and V.K. Jindal, Materials Science in Semiconductor Processing, 27, 79-96 (2014), https://doi.org/10.1016/j.mssp.2014.06.015.

[30] J.C. Rife, R.N. Dexter, P.M. Bridenbaugh, and B.W. Veal, Phys. Rev. B, 16, 4491 (1977), https://doi.org/10.1103/PhysRevB.16.4491.

[31] J.F. Nye, Physical Properties of Crystals, Their Representation by Tensors and Matrices, (Oxford Univ. Press, Oxford, USA, 1985).

[32] W. Voigt, Lehrbuch der Kristallphysik, (Teubner, Leipzig, 1928).

[33] I.R. Shein, and A.L. Ivanovskii, Scripta Materiali, 59, 1099-1002 (2008), https://doi.org/10.1016/j.scriptamat.2008.07.028.

[34] A. Reuss, and Z. Angew. Math. Mech. 9, 55 (1929), https://doi.org/10.1002/zamm.19290090104.

[35] R. Hill, Proc. Phys. Soc. Lond. A, 65, 349 (1952), https://doi.org/10.1088/0370-1298/65/5/307. 
[36] S.F. Pugh, Philos. Mag. 45, 823-843 (1953), https://doi.org/10.1080/14786440808520496.

[37] K. Chen, L. Zhao, and J.S. Tse, J. Appl. Phys. 93, 2414 (2003), https://doi.org/10.1063/1.1540742.

[38] K. Chen, L. Zhao, J.S. Tse, and J.R. Rodgers, Phys. Lett. A, 331, 400 (2004), https://doi.org/10.1016/j.physleta.2004.09.034.

[39] M.A. Blanco, E. Francisco, and V. Luaña, Comput. Phys. Commun. 158, 57 (2004), https://doi.org/10.1016/j.comphy.2003.12.001.

[40] M.A. Blanco, A. Martín Pendás, E. Francisco, J.M. Recio, and R. Franco, J. Mol. Struct. Theochem. 368, 245 (1996), https://doi.org/10.1016/S0166-1280(96)90571-0.

[41] M. Flórez, J.M. Recio, E. Francisco, M.A. Blanco, and A.M. Pendás, Phys. Rev. B, 66, 144112 (2002), https://doi.org/10.1103/PhysRevB.66.144112.

[42] E. Francisco, M.A. Blanco, and G. Sanjurjo, Phys. Rev. B, 63, 094107 (2001), https://doi.org/10.1103/PhysRevB.63.094107.

[43] J.P. Poirier, Introduction to the Physics of Earth's Interior, (Cambridge University Press, Oxford, 2000), pp. 39.

[44] A.S. Verma, and S.R. Bhardwaj, J. Phys: Condensed Matter, 19, 026213 (2007), https://doi.org/10.1088/0953-8984/19/2/026213.

[45] R. Gautam, P. Singh, S. Sharma, S. Kumari, and A.S. Verma, Superlattices and Microstructures, 85, 859-871 (2015), https://doi.org/10.1016/j.spmi.2015.07.014.

[46] B.G. Streetman, and S.K. Banerjee, Solid State Electronic Devices' 6th ed. (Pearson College Div, 2010), pp. 581.

[47] Y.P. Varshni, Physica, 34, 149 (1967), https://doi.org/10.1016/0031-8914(67)90062-6.

[48] B.O. Seraphin, editor, Solar Energy Conversion-Solid State Physics Aspects Topics in Applied Physics, Volume 31, (SpringerVerlag, Heidelberg, 1979), https://doi.org/10.1007/3-540-09224-2.

[49] S.M. Sze, Physics of semiconductor devices, 2nd ed. (John Wiley and Sons, NY, 1981), pp. 880.

[50] P. Wurfel, Physics of Solar Cells, (Wiley-VCH Verlag, Weinheim, 2005), pp. 188.

[51] V. Kumar, A.K. Shrivastava, R. Banerji, and D. Dhirhe, Solid State Communications, 149, 1008-1011 (2009), https://doi.org/10.1016/j.ssc.2009.04.003.

[52] A.S. Verma, S. Sharma, and V.K. Jindal, Mod. Phys. Letts. B, 24, 2511 (2010), https://doi.org/10.1142/S0217984910024821.

[53] A.S. Verma, Phys. Status Solidi B, 246, 192 (2009), https://doi.org/10.1002/pssb.200844242.

[54] A.S. Verma, and D. Sharma, Phys. Scr. 76, 22 (2007), https://doi.org/10.1088/0031-8949/76/1/004.

[55] K.F. Young, and H.P.R. Fredrikse, J. Phys. Chem. Ref. Data 2, 313 (1973), https://doi.org/10.1063/1.3253121.

[56] K.K. Kima, S. Niki, J.Y. Oh, J. Song, T.Y. Seong, S.J. Park, S. Fujita, and S.W. Kimb, J. Appl. Phys. 97, 066103 (2005), https://doi.org/10.1063/1.1863416.

[57] M.A. Bodea, G. Sbarcea, G.V. Naik, A. Boltasseva, T.A. Klar, and J.D. Pedarnig, Appl. Phys. A, 110, 929 (2013), https://doi.org/10.1007/s00339-012-7198-6.

[58] S. Mondal, S.R. Bhattacharyya, and P. Mitra, Pramana J. Physics, 80, 315 (2013), https://doi.org/10.1007/s12043-012-0463-6.

[59] R.K. Swank, Phys. Rev. 153, 844 (1967), https://doi.org/10.1103/PhysRev.153.844.

[60] Z.C. Feng, editor, Handbook of Zinc Oxide and Related Materials: Devices and Nano Engineering, Volume 2, (CRC Press/Taylor $\&$ Francis, Boca Raton, FL, 2012).

[61] M.A. Olopade, O.O. Oyebola, and B.S. Adeleke, Adv. Appl. Sci. Res. 3, 3396 (2012), https://www.researchgate.net/profile/ Muteeu_Olopade/publication/283294216_Investigation_of_some_materials_as_buffer_layer_in_copper_zinc_tin_sulphide_Cu 2ZnSnS4_solar_cells_by_SCAPS-1D/linkss/5699290108̄aea14769432a39.pdf.

[62] X. Yang, C. Xu, and N.C. Giles, J. Appl. Phys. 104, 073727 (2008), https://doi.org/10.1063/1.2996032.

[63] B.K. Meyer, ZnO: electron and hole mobilities, Landolt-Börnstein-Group III, Condensed Matter, 44D, 610 (2011).

[64] M. Burgelman, K. Decock, S. Khelifi, A. Abass, Thin Solid Films, 535, 296 (2013), https://doi.org/10.1016/j.tsf.2012.10.032.

[65] M.A. Green, Solar Cells, Operating Principles, Technology and System Applications, Prentice Hall Inc., (1982)

[66] W.E. Spear, J. Mort, Proc. Phys. Soc. 81, 130 (1963), https://doi.org/10.1088/0370-1328/81/1/319.

[67] M.S. Hossain, M.M. Aliyu, M.A. Matin, M.A. Islam, M.R. Karim, T. Razykov, K. Sopian, and N. Amina, Int. J. Mech. Mater. Eng. 6, 350 (2011).

[68] H.J. Moller, Progress in Materials Science 35, 205-418 (1991), https://doi.org/10.1016/0079-6425(91)90001-A.

[69] S. Siebentritt, U. Rau, Wide-Gap Chalcopyrites, (Springer, 2006).

\section{СТРУКТУРА І ВЛАСТИВОСТІ ZnSnР2 ДЛЯ ЗАСТОСУВАННЯ В ФОТОЕЛЕКТРИЧНИХ ПРИСТРОЯХ З ВИКОРИСТАННЯМ БУФЕРНИХ ШАРІВ НА ОСНОВІ CdS I ZnTe Нираджа , Аджай С. Верма}

${ }^{a}$ Фізичний факультет, Банасталі Від’япіт, Раджастан 304022 (Індія)

${ }^{b}$ Факультет природничих та прикладних наук, Школа технологій,Глокал університет Сахаранпур, Уттар Прадеш, 247232 (Індія)

Тут ми представляємо розширений аналіз параметрів, пов'язаних із структурними, електронними, оптичними та механічними властивостями халькопіритового матеріалу на основі цинку, використовуючи повний потенціал лінеаризованого методу доповненої плоскої хвилі (FP-LAPW) в рамках теорії функціональності щільності. Розрахунки ab initio виконувались методом лінеаризованої розширеної плоскої хвилі (LAPW), реалізованого в коді WIEN2K в рамках теорії функціоналу щільності, щоб отримати структурні, електронні та оптичні властивості ZnSnP2 у об'ємно-центрованій тетрагональній (ВСТ) фазі. Представлено шість пружних констант $\left(\mathrm{C}_{11}, \mathrm{C}_{12}, \mathrm{C}_{13}, \mathrm{C}_{33}, \mathrm{C}_{44}\right.$ i $\left.\mathrm{C}_{66}\right)$ та механічні параметри, які порівнюються 3 наявними експериментальними даними. Для точного опису залежності від тиску і температури коефіцієнта теплового розширення, об'ємного модуля, питомої теплоти, температури Дебая, параметрів ентропії Грюнайзена використовуються термодинамічні розрахунки в квазігармонічному наближенні. На основі напівемпіричного співвідношення ми визначили твердість матеріалу; що пояснюється різною силою ковалентного зв'язку. Крім того, змодельовані сонячних елементи на основі $\mathrm{ZnSnP} 2$, також проаналізовано фізику пристрою та параметри продуктивності для буферних шарів ZnTe та CdS. Результати моделювання для тонкошарової сонячної батареї $\mathrm{ZnSnP} 2$ показують максимальну ефективність $(22,9 \%)$ із ZnTe в якості буферного шару. Більшість досліджуваних параметрів повідомляється вперше. Результат цього дослідження додатково підтверджує перспективи використання цього халькопіриту, який за своєю суттю був би стійким та відповідав би гнучкому субстрату, що $\epsilon$ найважливішими характеристиками для комерціалізації сонячних елементів на основі халькопіриту. Таким чином, сприяння еволюції цього матеріалу для досягнення високоефективних оптоелектронних пристроїв відкриває новий шлях у галузі створення сонячних елементів.

КЛЮЧОВІ СЛОВА: Ab-initio розрахунки; електронні властивості; пружні константи; термодинамічні властивості 